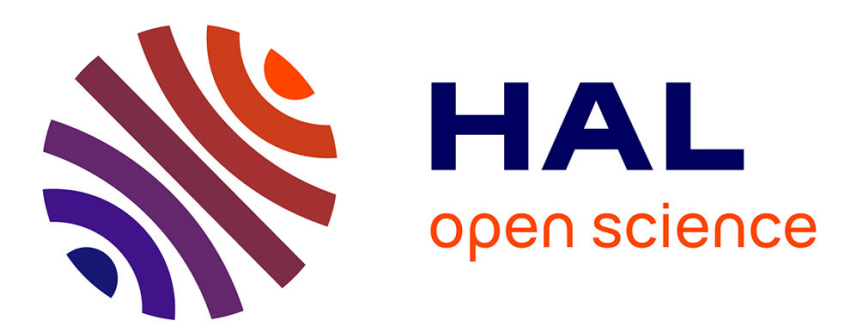

\title{
Efficiency evaluation procedure of coal-fired power plants with CO2 capture, cogeneration and hybridization
}

\author{
Hayato Hagi, Thibaut Neveux, Yann Le Moullec
}

\section{To cite this version:}

Hayato Hagi, Thibaut Neveux, Yann Le Moullec. Efficiency evaluation procedure of coal-fired power plants with $\mathrm{CO} 2$ capture, cogeneration and hybridization. Energy, 2015, 91, pp.306-323. 10.1016/j.energy.2015.08.038 . hal-01831812

\section{HAL Id: hal-01831812}

\section{https://hal-edf.archives-ouvertes.fr/hal-01831812}

Submitted on 6 Jul 2018

HAL is a multi-disciplinary open access archive for the deposit and dissemination of scientific research documents, whether they are published or not. The documents may come from teaching and research institutions in France or abroad, or from public or private research centers.
L'archive ouverte pluridisciplinaire HAL, est destinée au dépôt et à la diffusion de documents scientifiques de niveau recherche, publiés ou non, émanant des établissements d'enseignement et de recherche français ou étrangers, des laboratoires publics ou privés. 


\title{
Efficiency evaluation procedure of coal-fired power plants with $\mathrm{CO}_{2}$ capture, cogeneration and hybridization
}

\author{
Hayato Hagi ${ }^{\mathrm{a}, \mathrm{b}}$, Thibaut Neveux ${ }^{\mathrm{a}}$, Yann Le Moullec ${ }^{\mathrm{a}}$ \\ a EDF R\&D, 6 quai Watier, F-78401 Chatou, France \\ ${ }^{\mathrm{b}}$ MINES ParisTech, PSL - Research University, CES - Centre for energy efficiency of systems, 60 Bd St Michel, F-75272 Paris \\ Cedex 06, France
}

\section{ABSTRACT}

In an energy landscape undergoing great change with regard to $\mathrm{CO}_{2}$ emissions, the evaluation of solutions allowing a drastic reduction of the anthropogenic emissions are carried out for more than a decade. Among them, $\mathrm{CO}_{2}$ capture and storage on coal power plants has been identified as a particularly promising solution but other options such as heat and electricity cogeneration and power plant hybridization with solar or biomass can also reduce the carbon footprint of electricity production. However, the implementation of an external process on a power plant impacts its electric production. Post- and oxy-combustion $\mathrm{CO}_{2}$ capture, cogeneration for industries or districts, or hybridization are all examples of processes either demanding thermal and electrical energy or providing heat valorization opportunities. To identify the true potential of those systems, the evaluation of the performance of the integrated system is necessary. Also, to compare different solutions, a common framework has to be adopted since the performance of those system are often highly dependent of the considered hypotheses.

This paper presents a full integration procedure suited for both new built and retrofit coal-fired power plants by means of easy-to-use correlations, which links heat demand to production loss and waste heat availability to production increase, taking their exergy content into account. This correlative approach provides an analytical tool allowing a quick and realistic evaluation of a given concept or process layout, without the need of a detailed full power plant model. Examples are given for $\mathrm{CO}_{2}$ capture, cogeneration and hybridization, illustrating the interest of the approach to evaluate and compare several technologies on a consistent manner. An Excel spreadsheet with the calculation procedure is available online (see supporting information).

\section{Keywords}

$\mathrm{CO}_{2}$ capture, Post-combustion, Oxy-combustion, Power plant integration, Cogeneration, Hybridization

*Corresponding author. Tel:

E-mail address: yann.lemoullec@edf.fr 


\section{Introduction}

$\mathrm{CO}_{2}$ capture and storage is foreseen to play a significant role in greenhouse gas control reduction but the large-scale deployment of these technologies are limited by their high energy consumption leading to large loss of power plant efficiencies. These losses of efficiency lead to a significant cost of avoided $\mathrm{CO}_{2}$. Therefore, a proper evaluation of the power consumption related to the capture of the $\mathrm{CO}_{2}$, including heat integration opportunities, is critical for a correct assessment of a new technology since the impact of the capture system on the power plant is strongly technology dependent. Most of the capture processes dissipating large amount of heat, the evaluation of the valorization of the available heat sources by thermal integration is of a crucial importance since both their quantity and quality is largely case-dependent. The capture plant/power plant interface can be even more different within the large number of innovative new technologies described for $\mathrm{CO}_{2}$ capture such as vacuum or high pressure solvent regeneration, temperature swing adsorption, calcium looping or $\mathrm{O}_{2}$ transport membrane for example.

Numerous solutions can be found in literature to evaluate a capture process. Among them, the most widely used indicators are: specific energy consumption, power plant efficiency and cost of avoided $\mathrm{CO}_{2}$. Specific energy consumptions, which can either be the specific reboiler duty in solvent based post-combustion (mostly expressed in $\mathrm{GJ} / \mathrm{t}_{\mathrm{CO} 2}$ ) or separation power demand relative to air separation and flue gas purification (respectively expressed in $\mathrm{kWh} / \mathrm{t}_{02}$ and $\mathrm{kWh} / \mathrm{t}_{\mathrm{co}}$ ) are the most used one widespread. However, these figures are difficult to compare due to different units and different scopes. The power plant efficiency estimation allows direct, simple and uniform comparison between technologies but requires a detailed definition of the plant and fuel and additional calculations. Finally, the cost of avoided $\mathrm{CO}_{2}$ allows, also, a direct comparison between technologies but requires large amount of technical and financial hypotheses leading to significant difficulties when one wish to make the comparison between several studies. Since the loss of efficiency represents between 60 to $80 \%$ of the cost of avoided $\mathrm{CO}_{2}$, comparing the power plant efficiency is a relevant tradeoff between comparison accuracy and number of hypothesis.

On one hand, some studies propose methodologies to assess post-combustion solvent-based $\mathrm{CO}_{2}$ capture on a retrofitted power plant [1, 2] or an ideal power plant [3] and offer simulation-based correlations. In both case, the waste heat valorization is not taken into account. On the other hand, some studies have assessed the interest of waste heat valorization [4] but no correlation have been produced to help the evaluation of a given capture technology. To our knowledge, none of the approaches described in literature allows a simultaneous consideration of the stripper reboiler heat duty and waste heat valorization, which is of a crucial importance to properly assess the performance of a post-combustion $\mathrm{CO}_{2}$ capture process and perform reliable comparisons. Concerning the oxy-combustion application, while [5] and [6] have proposed pinch based methodologies for the integration of waste heat into the steam cycle, those approaches are rather time-consuming to implement. An alternative approach for ensuring an efficient valorization of waste heat sources is the use of exergy. By definition, exergy is the measure of the useful work contained in a system in a reference environment. Based on both the first and the second law of thermodynamics, exergy allows to take into account both the quantity and the quality of a heat source. In contrast with energy, exergy is not conservative. Consequently any real transformation, such as a heat exchange between two flows at finite temperature difference, leads to thermodynamic irreversibilities, which correspond to exergy losses. In this study, a heuristic approach minimizing the exergy losses for heat integration has been adopted and correlations allowing the assessment of the plant energy performances has been derived. The correlation-based methodology presented in this paper offers a straightforward tool allowing a realistic assessment of the gains brought by heat integration on the power plant efficiency.

This paper presents a full integration methodology suited for new built power plant or retrofit including waste heat valorization. Correlations, which link heat demand to production loss and waste heat availability to production increase, are also provided. Two examples are given as case studies for the two most mature $\mathrm{CO}_{2}$ capture technologies: amine-based postcombustion and cryogenic oxy-combustion. The main purpose of this work is not to compare different $\mathrm{CO}_{2} \mathrm{capture}$ technologies but to provide a generic methodology for realizing such comparison. Based on a reference state-of-the-art airfired power plant, this methodology allows the accurate accounting of a production loss to fulfill a heat demand or a production increase brought by waste heat valorization. Initially developed for CCS applications, this methodology has been extended for the assessment of other energy systems such as heat and electricity cogeneration and solar hybridization of a coal-fired power plant. A turnkey Excel spreadsheet allowing users to assess the energetic performances of different integrated systems has been provided (see supporting information).

\section{1. $\mathrm{CO}_{2}$ capture generalities}

Regardless the employed process, capturing the $\mathrm{CO}_{2}$ produced by a coal-fired power plant leads to an efficiency decrease [7]. Indeed, compared to a conventional air-fired power plant without carbon capture, the introduction of a capture system induces an electric production drop for a given coal input, the nature of this decrease depending on the adopted capture technology.

In post-combustion capture, the power plant layout is preserved and the $\mathrm{CO}_{2}$ is separated in an end-of-pipe manner. This technology thus consists in installing a capture unit between the classical flue gas cleaning steps and the stack (see Figure 1). Since the boiler operates at near atmospheric pressure with air as oxidizer, the $\mathrm{CO}_{2}$ partial pressure in the flue gas is relatively low (around $13 \%$ vol on a wet basis). Regardless the considered post-combustion process, the carbon dioxide separation unit requires either thermal power or electrical power or both, in addition to the compression work. In order to provide the 
thermal duty, a steam extraction can be performed on the steam cycle. After condensing in a heat exchanger to release its latent heat, the water is returned back to the steam cycle. The most common post-combustion process is based on reversible absorption of $\mathrm{CO}_{2}$ in an amine aqueous solution; the $\mathrm{CO}_{2}$ desorption from the solvent is carried out at high temperature and required a significant amount of heat. Consequently, amine-based capture requires an additional unit as well as steam extraction and water reinjection on the steam cycle.

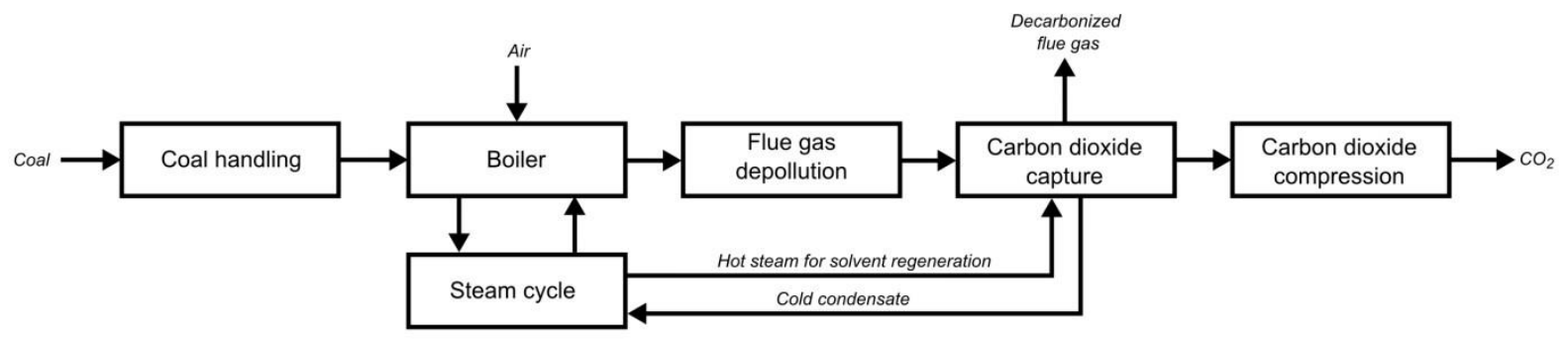

Oxy-combustion consists in combusting the coal in a nitrogen depleted environment in order to facilitate the downstream capture step. The flame temperature is controlled by dilution of the oxygen provided by the air separation unit (ASU); to that end a portion of the flue gas, mainly composed of $\mathrm{CO}_{2}$ and water vapor, is recycled. Finally, in order to separate the impurities, mainly induced by air ingress occurring in the boiler and in the flue gas depollution train, a flue gas purification process has to be employed. Also ensuring the compression of the $\mathrm{CO}_{2}$ up to the transport specifications, this process is called compression and purification unit (CPU). Thus, capture by oxy-combustion requires two additional units, an oxygen separation process (ASU) upstream the boiler island and a downstream purification and compression process (CPU) and the structural modification of the boiler and flue gas depollution island by the introduction of a flue gas recycle (see Figure 2).

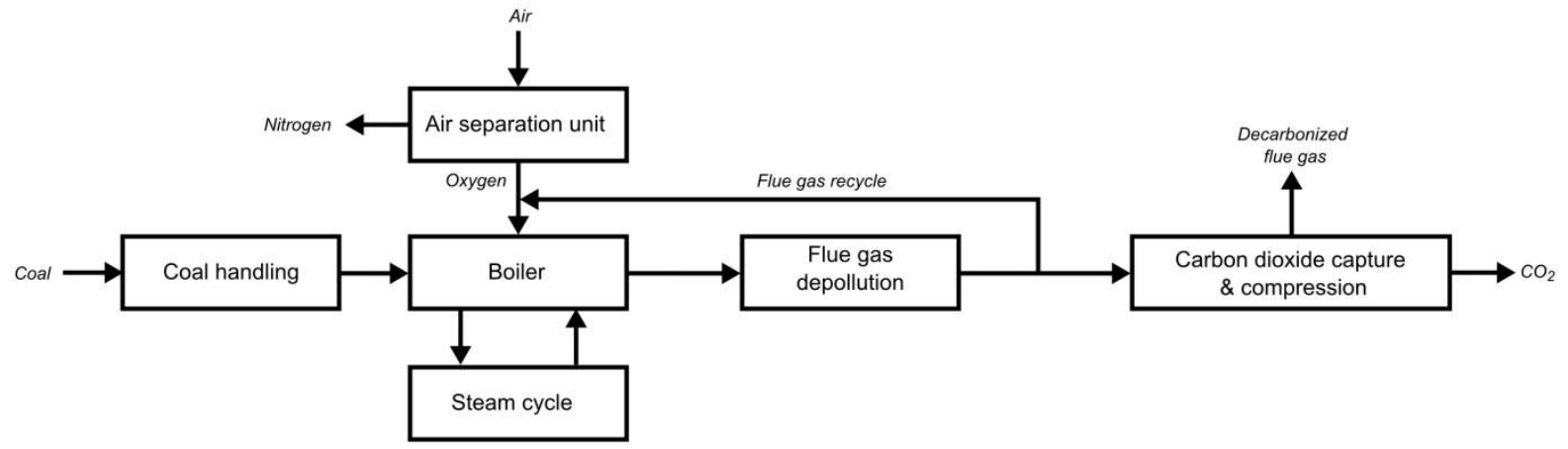

Figure 2 Simplified block flow diagram of the power plant with an oxy-combustion capture system

\section{2. $\mathrm{CO}_{2}$ capture process performance assessment}

The overall performance of a power plant can be calculated by one the following equivalent expressions:

- energy penalty $(w)$ expressed in $\mathrm{kWh}$ per metric ton of captured $\mathrm{CO}_{2}\left(\mathrm{kWh} / \mathrm{t}_{\mathrm{CO} 2}\right)$ :

$$
w\left(k W h / t_{\mathrm{CO}_{2}}\right)=\frac{W_{\text {capture }}-W_{\text {integ }}}{\dot{m}_{\text {CO2 captured }}}
$$

- $\quad$ net plant efficiency $\left(\eta_{C C S}\right)$ expressed in \%LHV:

$$
\eta_{C C S}\left(\%_{L H V}\right)=100\left(\frac{W_{\text {net ref }}-W_{\text {capture }}+W_{\text {integ }}}{Q_{\text {heat boiler }}}\right)
$$

- loss of efficiency $\left(\Delta \eta_{C C S}\right)$ expressed in \%-pts LHV: $_{\text {: }}$

$\Delta \eta_{C C S}\left(\%-p t s_{L H V}\right)=\eta_{\text {ref }}-\eta_{C C S}$ 
- $\quad$ specific energy cost of avoided $\mathrm{CO}_{2}$ (SPECCA) in $\mathrm{kg}_{\mathrm{CO} 2} / \mathrm{kWh}$ :

$$
\operatorname{SPECCA}\left(\mathrm{kg}_{\mathrm{CO}_{2}} / k W h\right)=\frac{1 / \eta_{\mathrm{CCS}}-1 / \eta_{\text {ref }}}{e_{\mathrm{CO}_{2}, \mathrm{ref}}-e_{\mathrm{CO}_{2}, \mathrm{CCS}}}
$$

In the next part of this article, both energy penalty and loss of efficiency are used as performance indicators.

\section{Methodology}

\subsection{Reference air-fired power plant}

In order to properly assess the performance of a $\mathrm{CO}_{2}$ capture process, the setup of a reference air-fired power plant is mandatory. The lower the efficiency of the reference plant is, the higher the $\mathrm{CO}_{2}$ content of the power produced $\left(\mathrm{gCO}_{2} / \mathrm{kWh}\right)$, so the net plant efficiency decrease (energy penalty) induced by the capture is naturally more important for a given process. It is also important to have consistency in the modeling approach and in the adopted set of hypotheses when comparing several capture technologies. This section describes the adopted referential proposed in this study. It has to be stressed out that the plant modeled in this study is a generic standard high efficiency plant, neither referring to a specific site nor representing an actual power plant project.

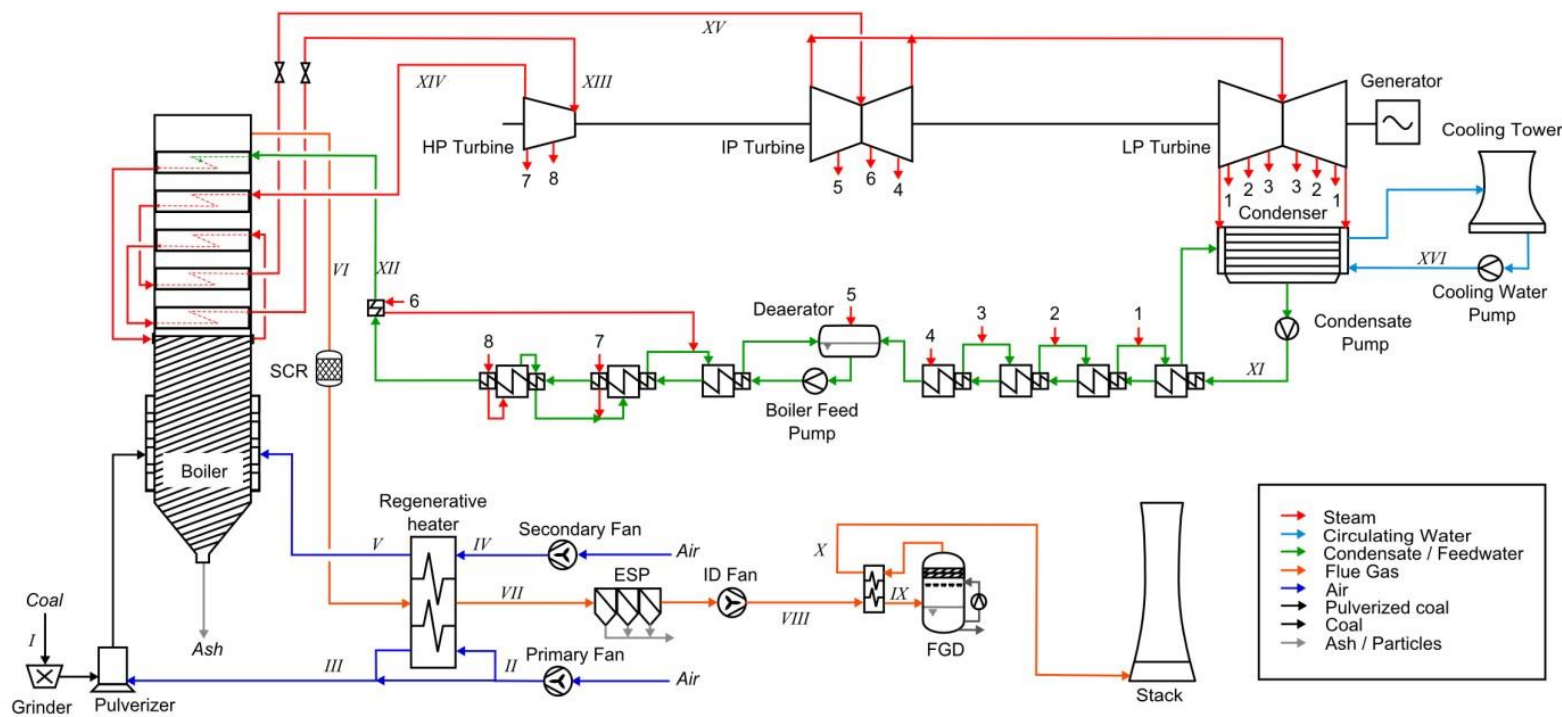

Figure 3 Simplified PFD of the reference air-fired power plant

The commercial simulation software Aspen Plus ${ }^{\circledR} 7.2$ is used to model the performance of the reference air-fired power plant; base-load and steady-state operation are supposed. For the sake of consistency with other European studies, such as [8], the recommendations stated by the European Benchmarking Task Force [9] are adopted: high quality Douglas Premium coal with a lower heater value (LHV) of $25.2 \mathrm{MJ} / \mathrm{kg}$ is considered and ISO conditions for an inland construction are applied for ambient pressure $(1.013 \mathrm{bar})$, temperature $\left(15^{\circ} \mathrm{C}\right)$ and relative humidity $(60 \%)$. The net plant output of the considered plant is $975 \mathrm{MW}_{\mathrm{e}}$. The power plant is represented in Figure 3 and the main operating points of the process are displayed in Table 1. 
Table 1 Operating parameters of the reference plant major streams pictured in Figure 3

\begin{tabular}{cccc}
\hline & Flowrate $(\mathrm{t} / \mathrm{h})$ & $\mathrm{T}\left({ }^{\circ} \mathrm{C}\right)$ & $\mathrm{P}($ bar $)$ \\
\hline I & 301 & 15 & 1.01 \\
II & 693 & 28 & 1.13 \\
III & 624 & 110 & 1.12 \\
IV & 2519 & 18 & 1.04 \\
V & 2463 & 310 & 1.03 \\
VI & 3428 & 340 & 0.99 \\
VII & 3555 & 121 & 0.96 \\
VIII & 3695 & 129 & 1.06 \\
IX & 3695 & 90 & 1.06 \\
X & 3789 & 88 & 1.02 \\
XI & 2148 & 32 & 19.0 \\
XII & 2873 & 315 & 325 \\
XIII & 2873 & 600 & 300 \\
XIV & 2401 & 354 & 66.1 \\
XV & 2401 & 620 & 60.0 \\
XVI & 83774 & 18 & 3.30 \\
\hline
\end{tabular}

Boiler island

The boiler, operating in slight vacuum to ensure safe operation, is modeled as a Gibbs reactor operating at the furnace average temperature $\left(1250^{\circ} \mathrm{C}\right)$ and six heat exchangers. Heat released by the combustion is transferred to the steam cycle in the heat exchangers representing the waterwall tubes, three feedwater (FW) superheaters and the two steam resuperheaters. The temperature difference between the preheated feedwater and the flue gas exiting the boiler is $25 \mathrm{~K}$ and the reheater pinch temperature is $30 \mathrm{~K}$. An oxygen excess at boiler outlet of $3.2 \%$ mol, an air ingress in the boiler of $1.5 \% \mathrm{wt}$ and an unconverted carbon ratio of 0.01 are considered.

Flue gas depollution island

Flue gas exiting the boiler successively undergoes denitrification in a selective catalytic reduction unit (SCR), cooling down against the inlet air in a regenerative heater (RH), particles removal in an electrostatic precipitator (ESP) and desulfurization in a wet flue gas desulfurization unit (WFGD). The depolluted flue gas is reheated in a regenerative heater against sulphur rich flue gas and sent to the stack. For safety issues, a portion of the primary air bypasses the $\mathrm{RH}$ to reduce the temperature of the flow heading the coal preparation section down to $110^{\circ} \mathrm{C}$.

\section{$\underline{\text { Steam cycle island }}$}

A state-of-the-art ultra-supercritical single reheat Hirn steam cycle with steam conditions of $300 \mathrm{bar} / 600{ }^{\circ} \mathrm{C} / 620{ }^{\circ} \mathrm{C}$ is considered. The reheat pressure is 60 bar and the vapor fraction at the outlet of the low-pressure turbine is 0.89 . The preheating of the feedwater is realized by steam bleedings in seven indirect heat exchangers and a direct contact heat exchanger also playing the role of deaerator. The first bleeding after the reheat (bleeding 6 in Figure 3 ) is desuperheated at the top of the FW preheating train. Regarding heat rejection, a natural draught cooling tower providing a cold source of $18.2^{\circ} \mathrm{C}$, which corresponds to a 48 mbar saturation pressure, is employed. The isentropic efficiencies of the high-pressure (outlet pressure $>50 \mathrm{bar}$ ) and intermediate pressure (outlet pressure $>5$ bar) steam turbines are respectively $92 \%$ and $94 \%$ according to the EBTF. Concerning the low-pressure turbines, an efficiency of $90 \%$ has been assessed when no condensation occurs and $88 \%$ otherwise. A FW preheater pinch temperature of $5 \mathrm{~K}$ (at saturation) has been assessed.

The overall performances of the reference power plant are shown in Table 2.

Table 2 Reference plant performances

\begin{tabular}{lcc}
\hline Steam turbine generator output (gross) & $\mathrm{MW}$ & 1082.2 \\
Power block auxiliary power & $\mathrm{MW}$ & 48.6 \\
Other auxiliaries power and transformer losses & $\mathrm{MW}$ & 58.7 \\
Total auxiliary power & $\mathrm{MW}$ & 107.3 \\
Heat input & $\mathrm{MW}_{\mathrm{th}}$ & 2112.7 \\
Emissions & $\mathrm{g}_{\mathrm{CO} 2 / \mathrm{kWh}}$ & 749 \\
Steam generator fuel efficiency & $\%_{\mathrm{LHV}}$ & 98.6 \\
Gross plant efficiency & $\%_{\mathrm{LHV}}$ & 51.2 \\
Net plant efficiency & \%LHV & 46.1 \\
\hline
\end{tabular}


With this defined reference power plant without capture process, calculation can be carried out to assess the impact of steam extraction and heat insertion in the steam cycle. The heat integration methodology is described in the next section followed by the methodology used for the steam extraction.

\subsection{Evaluation methodology for heat production}

Several capture processes need low to medium temperature heat duties. Since, the steam cycle of a power plant can be considered as a potential high efficiency cogeneration plant; it is convenient to provide the needed heat duty through steam extraction from this power cycle. The resulting loss of production is often named parasitic load. It is quite straightforward to express this parasitic load with generic process variables such as flow rates, temperature, heat duty or pressure. Since this term can be complex to estimate only using information focused on the capture process, the objective of this paper is to provide a method to evaluate the energy penalty using the main process parameters of the capture unit as inputs.

The parasitic load being the reflection of the integration between the capture unit and the steam cycle, its value will strongly depend on the chosen integration strategy. In this work, two different strategies are investigated: a retrofit case and a newbuild case (displayed in Figure 4).

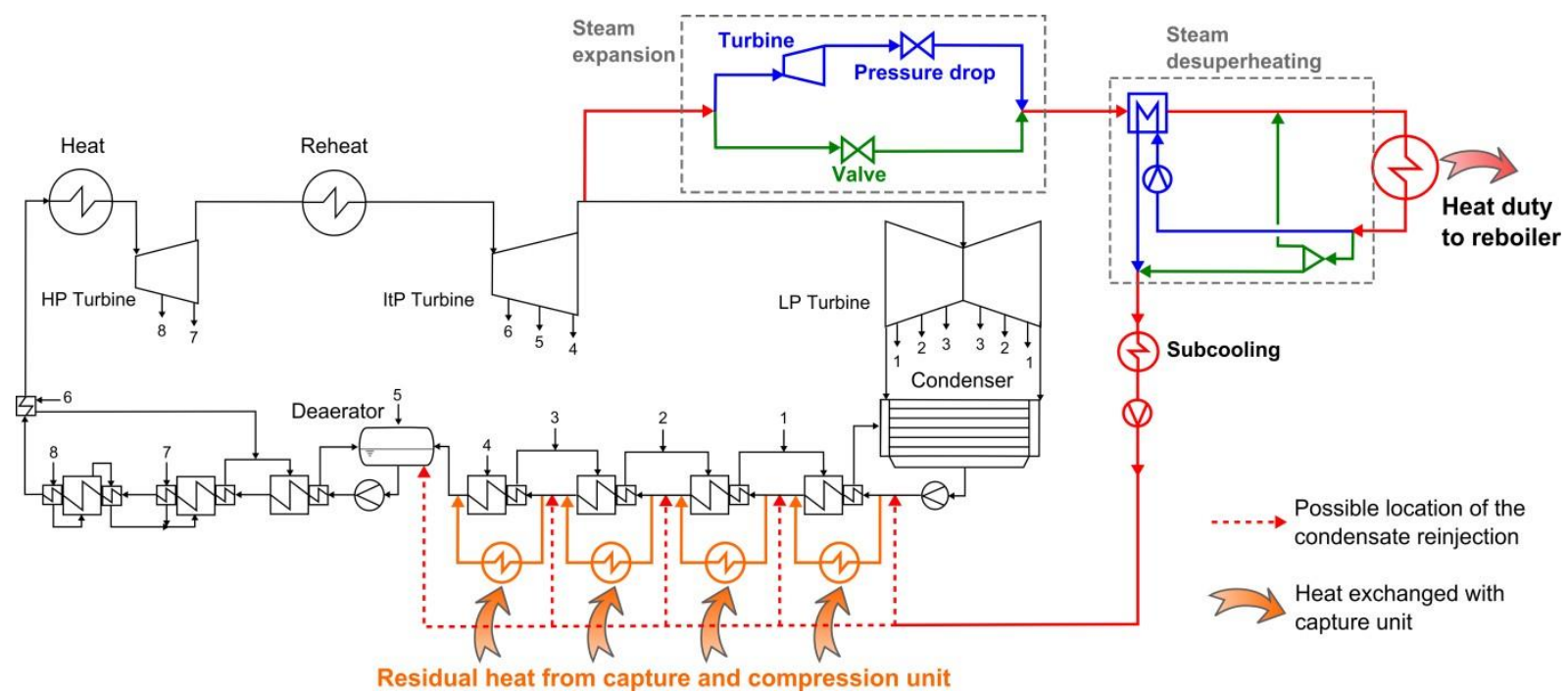

Figure 4 Integration strategies between post-combustion capture unit and steam cycle (green: retrofit, blue: new-build)

For both cases, the steam is extracted on the crossover pipe (allowing a maximal temperature of approximately $170{ }^{\circ} \mathrm{C}$ ) and its pressure is adapted to fit with capture unit requirements; the expansion is performed with a valve for the retrofit and a turbine for the new-build. The steam de-superheating can be performed by mixing with a fraction of the condensate (retrofit) or by introducing an additional heat exchanger (new-build) as proposed by [10]. The steam condensate can be subcooled as proposed in some process flow schemes patented by MHI [11]. Finally, the condensate is sent back to the feedwater preheating train at the most appropriate temperature level. It should be stressed out that for a new-build case, the turbines could be designed so that the crossover pipe pressure is equal to the required pressure for capture unit taking into account the pressure drop in the transport pipe. In fact, if the additional turbine represents an adaptation of the IP turbine, its isentropic efficiency should be the same than the previous IP turbine, if the additional turbine represents a new equipment, its isentropic efficiency should be significantly lower (i.e. from 75 to $85 \%$ ).

Using these two different integration strategies, a complete design of experiment has then been carried out under AspenPlus to cover a wide range of capture process parameters in order to propose simple correlations. For all points used for regression and validation, the correlations represent the energy penalty with a mean absolute deviation of $0.8 \mathrm{kWh} / \mathrm{t}$, which represents $0.02 \%$-pts in terms of energy penalty.

The parasitic load is expressed as the sum of three terms: $w_{\text {steam }}$ related to the condensation of steam (e.g. a reboiler heat duty); $w_{\text {subcool }}$ relative to the subcooling of the condensate; and $w_{\text {turb }}$ referring to the power recovered by the expansion of the steam in a turbine:

$w_{\text {Parastic }}=w_{\text {steam }}+w_{\text {subcool }}-w_{\text {turb }}$

The parasitic load is consequently a function of the steam temperature $T_{\text {steam }}$; the heat quantity $q_{\text {steam }}$; the temperature variation $\Delta T_{\text {sub }}$ due to condensate subcooling; and the turbine isentropic and mechanicalefficiencies (respectively $\eta_{\text {turb }}$ and $\left.\eta_{\text {mech }}\right)$.

In equation (6), the temperature is the steam temperature and not the reboiler temperature. For process involving a reboiler, a pinch must be added for a proper use of these correlations, this choice permits the determination of the optimal pinch temperature for each process. 
These correlations are valid in the range of 0.1 to $5.0 \mathrm{GJ} / \mathrm{t}_{\mathrm{co} 2}$ for $q_{\text {steam }} ; 50$ to $170{ }^{\circ} \mathrm{C}$ for $T_{\text {steam }}$; and 0 to $40 \mathrm{~K}$ for $\Delta T_{\text {subcool }}$. A constant pressure drop of 0.3 bar has been considered between the turbine and the capture unit. The retained correlations are as follows and the corresponding coefficients are reported in Table 3:

$$
\left\{\begin{array}{l}
W_{\text {steam }}\left[\mathrm{MW}_{\mathrm{e}}\right]=Q_{\text {steam }}\left(a_{0}+a_{1} T_{\text {steam }}+a_{2} T_{\text {steam }}^{2}+\frac{a_{3}}{Q_{\text {steam }}}\right) \\
W_{\text {subcool }}\left[\mathrm{MW}_{\mathrm{e}}\right]=Q_{\text {steam }} \Delta T_{\text {subcool }}\left(b_{0}+b_{1} T_{\text {steam }}+b_{2} T_{\text {steam }}^{2}\right) \\
W_{\text {turb }}\left[\mathrm{MW}_{\mathrm{e}}\right]=\eta_{\text {turb }} \eta_{\text {mech }} Q_{\text {steam }}\left(c_{0}+c_{1} T_{\text {steam }}+c_{2} T_{\text {steam }}^{2}\right)
\end{array}\right.
$$

Or directly in kWh per metric ton of capture $\mathrm{CO}_{2}$ for $\mathrm{CO}_{2}$ capture evaluation, using steam demand (reboiler heat duty) in $\mathrm{GJ} / \mathrm{t}_{\mathrm{CO} 2}$ :

$$
\left\{\begin{array}{l}
w_{\text {steam }}\left[\mathrm{kWh} / \mathrm{t}_{\mathrm{CO} 2}\right]=q_{\text {steam }}\left(a_{0}+a_{1} T_{\text {steam }}+a_{2} T_{\text {steam }}^{2}+\frac{a_{3}}{q_{\text {steam }}}\right) \cdot \frac{1000}{3.6} \\
w_{\text {subcool }}\left[\mathrm{kWh} / \mathrm{t}_{\mathrm{CO} 2}\right]=q_{\text {steam }} \Delta T_{\text {subcool }}\left(b_{0}+b_{1} T_{\text {steam }}+b_{2} T_{\text {steam }}^{2}\right) \cdot \frac{1000}{3.6} \\
w_{\text {turb }}\left[\mathrm{kWh} / \mathrm{t}_{\mathrm{CO} 2}\right]=\eta_{\text {turb }} \eta_{\text {mech }} q_{\text {steam }}\left(c_{0}+c_{1} T_{\text {steam }}+c_{2} T_{\text {steam }}^{2}\right) \cdot \frac{1000}{3.6}
\end{array}\right.
$$

With $T_{\text {steam }}$ in ${ }^{\circ} \mathrm{C}, Q_{\text {steam }}$ in $\mathrm{MW}_{\text {th }}$ and $q_{\text {steam }}$ in $\mathrm{GJ} / \mathrm{t}_{\mathrm{CO} 2}$.

The coefficients of equations(6) and (7) are reported in Table 3 for three cases according to the steam expansion (valve of turbine) and desuperheating (direct or indirect) strategies.

The Figure 5 shows the evolution of parasitic load as function of $q_{\text {steam }}$ and $T_{\text {steam }}$ without subcooling and for the retrofit case. As expected, the loss of electric production increases strongly with both the steam quantity and quality. As already stressed by many authors, the consideration of both of this two aspects - and not only the reboiler heat duty - is of a crucial importance to properly evaluate the energy performance of a given capture unit.

Table 3 Coefficients of equations (6) and (7)

\begin{tabular}{ccccc}
\hline $\begin{array}{c}\text { Expansion } \\
\text { Desuperheating }\end{array}$ & Unit & $\begin{array}{c}\text { Valve } \\
\text { Direct }\end{array}$ & $\begin{array}{c}\text { Turbine } \\
\text { Direct }\end{array}$ & $\begin{array}{c}\text { Turbine } \\
\text { Indirect }\end{array}$ \\
\hline$a_{0}$ & - & 0.2481 & 0.3288 & 0.3185 \\
$a_{1}$ & ${ }^{\circ} \mathrm{C}^{-1}$ & $3.524810^{-4}$ & $2.149210^{-4}$ & $4.657910^{-4}$ \\
$a_{2}$ & ${ }^{\circ} \mathrm{C}^{-2}$ & $-1.167910^{-6}$ & $-3.136310^{-6}$ & $-4.427610^{-6}$ \\
$a_{3}$ & $\mathrm{MW}_{\text {th }}(6), \mathrm{GJ} / \mathrm{t}_{\mathrm{CO} 2}(7)$ & 0 & $1.347110^{-3}$ & $1.360110^{-3}$ \\
\hline$b_{0}$ & ${ }^{\circ} \mathrm{C}^{-1}$ & $1.381610^{-4}$ & $1.381610^{-4}$ & $-8.512310^{-5}$ \\
$b_{1}$ & ${ }^{\circ} \mathrm{C}^{-2}$ & $1.352110^{-7}$ & $1.352110^{-7}$ & $3.978110^{-6}$ \\
$b_{2}$ & ${ }^{\circ} \mathrm{C}^{-3}$ & $1.251010^{-8}$ & $1.251010^{-8}$ & $2.364410^{-9}$ \\
\hline$c_{0}$ & - & 0 & -0.3361 & -0.3231 \\
$c_{1}$ & - & 0 & $9.241910^{-4}$ & $6.454910^{-4}$ \\
$c_{2}$ & ${ }^{\circ} \mathrm{C}^{-1}$ & 0 & $6.060610^{-6}$ & $7.148510^{-6}$ \\
\hline
\end{tabular}

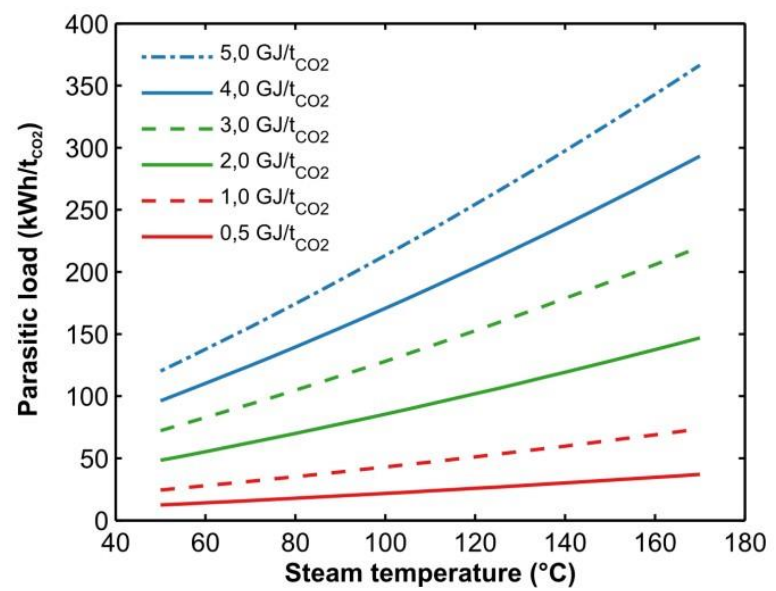

Figure 5 Parasitic load without subcooling as function of $Q_{\text {steam }}$ and $T_{\text {steam }}$ for a new-build case

\subsection{Evaluation methodology for heat integration}

When heat sources and heat sinks are available in a given process, the adopted integration pattern has a direct impact on the global system performance increase. Indeed, heat exchanges between two fluxes inducing unavoidable exergy losses due to finite temperature differences, rational integration methodology allows the minimization of those irreversibilities. In this 
section, a methodology allowing the evaluation of the power recovery potential of a given process layout in a straightforward manner is presented.

In this study, a systematic heat integration methodology using boiler feedwater of the steam cycle is proposed. As illustrated in Figure 6, FW is available in large quantity at liquid state in a broad range of temperature (from 32 to $310{ }^{\circ} \mathrm{C}$ ) and the introduction of heat exchangers in parallel of the FW preheaters allows an efficient valorization of the excess heat available elsewhere in the system. Indeed, this solution allows the adjustment of the feedwater flowrate heading the parallel heat exchanger (noted PHX) so that the temperature difference between the hot flow and the FW is maintained as close as possible to the pinch temperature along the heat exchanger. In addition to that, the physical state of the FW allows minimized pinch temperature at fixed heat exchanger area compared to the integration of the heat in a gaseous flow.

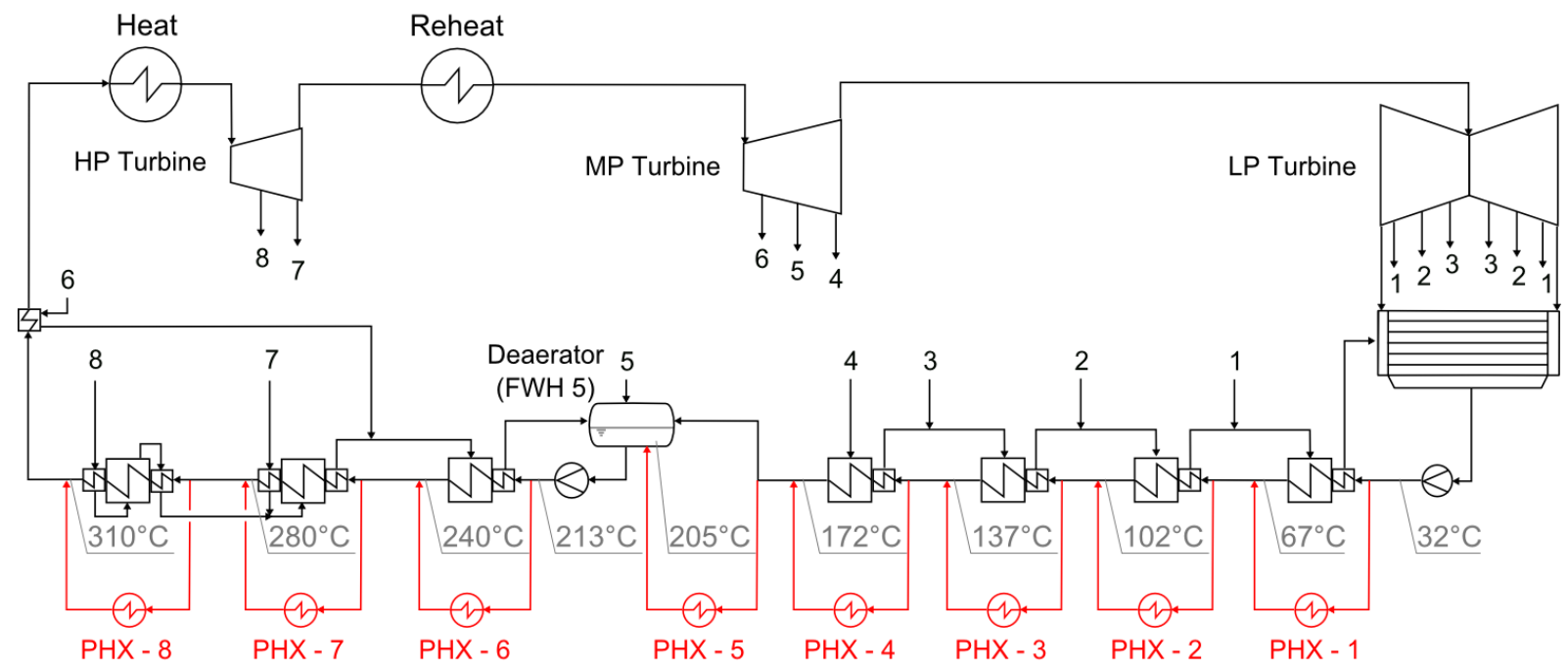

Figure 6 Simplified flow scheme of the steam cycle with the parallel heat exchangers for excess heat valorization

Heat integration in a parallel heat exchanger leads to the decrease of the heat demand in the associated FW preheater. Since the heating demands of those preheaters are provided by steam bleedings, heat integration in a parallel heat exchanger leads to an increased flowrate though the turbines placed downstream the associated FW preheater, increasing the electricity production. Thus, the higher the temperature at which a given amount of heat is available, the higher the amount of recovered electricity is.

In the approach proposed in this paper, each of the 8 parallel heat exchangers PHX-i is considered as the heat source of a sub-cycle with an associated marginal efficiency $\left(\eta_{i}\right)$. A sensitivity analysis has been performed in order to evaluate the influence of the integrated heat duty on the marginal efficiency for each of the parallel heat exchanger. The average absolute relative difference deviations (AARD) to the mean marginal efficiency of each parallel heat exchanger being below $0.1 \%$ for the low pressure section of the preheating train (PHX-1 to 5) and respectively $0.4 \%, 0.7 \%$ and $1.7 \%$ for PHX-6, PHX-7 and $\mathrm{PHX}-8$, the marginal efficiencies of the 8 parallel heat exchangers are assumed to be constant and equal to the mean values reported in Table 4 . When heat is required in the capture process, the parallel heat exchangers can also provide the duty at the desired temperature to the heat sink with the same marginal efficiency.

Table 4 Constant marginal efficiencies relative to the 8 parallel heat exchangers considered for heat integration

\begin{tabular}{lccc}
\hline & $\mathrm{T}_{\text {cold in }}\left({ }^{\circ} \mathrm{C}\right)$ & $\mathrm{T}_{\text {cold out }}\left({ }^{\circ} \mathrm{C}\right)$ & $\eta_{\mathrm{i}}\left(\mathrm{MW}_{\mathrm{e}} / \mathrm{MW}_{\text {th }}\right)$ \\
\hline $\mathrm{PHX}-1$ & 32 & 67 & 0.091 \\
$\mathrm{PHX}-2$ & 67 & 102 & 0.161 \\
$\mathrm{PHX}-3$ & 102 & 137 & 0.225 \\
$\mathrm{PHX}-4$ & 137 & 172 & 0.277 \\
$\mathrm{PHX}-5$ & 172 & 205 & 0.330 \\
$\mathrm{PHX}-6$ & 213 & 240 & 0.363 \\
$\mathrm{PHX}-7$ & 240 & 280 & 0.403 \\
$\mathrm{PHX}-8$ & 280 & 310 & 0.439 \\
\hline
\end{tabular}

Each heat source identified in the capture process has to be subdivided into several heat sources according to their temperature in order to determine the duty available for integration in each PHX. A pinch temperature, fixed at $10 \mathrm{~K}$ in this study according to common sizing heuristics related to gas-liquid heat exchanges, has to be considered during this step for realistic evaluation. The same goes for the heat sinks. Once this step completed, the heat duties to be integrated in each PHX 
are summed (positive for the heat integrated into the steam cycle and negative for the duty provided to a heat sink) in order to obtain the total amount of heat available in each temperature range $\left(Q_{P H X-I, \text { available }}\right)$ and the total additional work recovered by heat integration $\left(W_{\text {integ }}\right.$ ) can be assessed using:

$$
W_{\text {integ }}\left[\mathrm{MW}_{\mathrm{e}}\right]=\sum_{i=1}^{8} \eta_{i} \cdot Q_{P H X-i, \text { integ }}\left[\mathrm{MW}_{\mathrm{th}}\right]
$$

where the integrated heat duty in parallel heat exchanger i $Q_{P H X-i \text { integ }}$ (in $\mathrm{MW}_{\mathrm{th}}$ ) depends on the heat duty available at the corresponding temperature range and maximum heat duty that can be integrated.

While the FW flow is important, each parallel heat exchanger has a maximum heat duty that can be integrated $\left(Q_{\text {max, }} P H X-i\right)$. The identification of this value is of a crucial importance in order to respect the feasibility of a heat integration pattern. $Q_{\text {max }}$ $\mathrm{PHX}-\mathrm{i}$ varies within the amount of heat integrated in the upstream parallel heat exchangers and simulations have been carried out to determine the nature of this dependency. It appears that the maximum amount of heat that can be integrated in a parallel heat exchanger increases linearly with the duty integrated upstream and the contributions of each of the 8-i parallel heat exchangers are independent.

In addition, if a steam extraction is performed, the feedwater flowrate across the first preheaters (before the condensate reinjection point) is reduced, leading to a decrease of the maximum heat. The fraction of water extracted can be estimated using the following correlation:

$x_{\text {extraction }}=Q_{\text {steam }}\left(\alpha+\beta T_{\text {steam }}\right)$

Where $Q_{\text {steam }}$ is in $\mathrm{MW}_{\text {th }}$ and $T_{\text {steam }}$ in ${ }^{\circ} \mathrm{C}$. Thecoefficients for retrofit and new-build cases are reported in Table 5 .

Table 5 Coefficients of equation 9 for calculation of fraction of steam extracted

\begin{tabular}{ccccc}
\hline $\begin{array}{c}\text { Expansion } \\
\text { Desuperheating }\end{array}$ & Unit & $\begin{array}{c}\text { Valve } \\
\text { Direct }\end{array}$ & $\begin{array}{c}\text { Turbine } \\
\text { Direct }\end{array}$ & $\begin{array}{c}\text { Turbine } \\
\text { Indirect }\end{array}$ \\
\hline$\alpha$ & $\mathrm{MW}_{\mathrm{th}^{-1}}$ & $2.961210^{-4}$ & $4.155310^{-4}$ & $3.788010^{-4}$ \\
$\beta$ & $\mathrm{MW}_{\mathrm{th}}^{-1} \cdot{ }^{\circ} \mathrm{C}^{-1}$ & $5.814910^{-7}$ & $7.573110^{-8}$ & $4.432110^{-7}$ \\
\hline
\end{tabular}

And the reinjection location point is the point between feedwater preheaters whose temperature is the closest of the water reinjected, i.e. the temperature difference $T_{\text {steam }}-\Delta T_{\text {subcool }}$.

Consequently, the following equation can be formulated to sequentially calculate the maximum and actual heat duties integrated in parallel heat exchangers:

$$
Q_{P H X-i, i n t e g}=\min \left(Q_{P H X-i, a v a i l a b l e}, Q_{P H X-i, \max }\right)
$$

Where the maximum heat that can be valorized is calculated as follows:

$$
Q_{P H X-i, \max }=x_{\text {liq }}\left(Q_{\max , P H X-i}^{0}+\sum_{j=1}^{8} a_{i, j}\left(Q_{P H X-j, i n t e g}\right)\right)
$$

In this equation, $Q_{\max , P H X-i}^{0}$ is the maximum amount of heat that can be integrated in the parallel heat exchanger $\mathrm{i}$ when no heat is integrated in the other parallel heat exchangers (reported in Table 6), $a_{i, j}$ a coefficient associated to the parallel heat exchanger $\mathrm{j}$ and $Q_{P H X-j, i n t e g}$ thetotal heat duty integrated in the upstream parallel heat exchanger $\mathrm{j}$. The values of $Q_{\max , P H X-i}^{0}$ and $a_{i, j}$ coefficients have been gathered in Table 6. $x_{\text {liq }}$ is equal to 1 by default. In the case of steam extraction on the steam cycle, for example for solvent regeneration in post-combustion, the water flowrate is reduced before the reinjection point of steam condensate. In this case, $x_{\text {liq }}=1-x_{\text {extraction }}$ for the preheaters located downstream the reinjection point, and $x_{\text {liq }}=1$ upstream.

Table $6 Q_{\max , P H X-i}^{0}$ and the $a_{i, j}$ coefficients determined by simulation

\begin{tabular}{|l|c|c|c|c|c|c|c|c|}
\hline & $Q_{\max , P-i}^{0}(\mathrm{MW})$ & $\mathrm{a}_{\mathrm{i}, 2}(-)$ & $\mathrm{a}_{\mathrm{i}, 3}(-)$ & $\mathrm{a}_{\mathrm{i}, 4}(-)$ & $\mathrm{a}_{\mathrm{i}, 5}(-)$ & $\mathrm{a}_{\mathrm{i}, 6}(-)$ & $\mathrm{a}_{\mathrm{i}, 7}(-)$ & $\mathrm{a}_{\mathrm{i}, 8}(-)$ \\
\hline PHX-1 & 71.47 & 0.0595 & 0.0548 & 0.0510 & 0.0464 & 0.0442 & 0.0413 & 0.0389 \\
\hline PHX-2 & 77.38 & & 0.0594 & 0.0553 & 0.0502 & 0.0479 & 0.0446 & 0.0421 \\
\hline PHX-3 & 83.27 & & & 0.0596 & 0.0541 & 0.0514 & 0.0480 & 0.0452 \\
\hline PHX-4 & 90.24 & & & & 0.0586 & 0.0556 & 0.0519 & 0.0489 \\
\hline PHX-5 & 82.16 & & & & & 0.0878 & 0.0839 & 0.0787 \\
\hline PHX-6 & 79.42 & & & & & & 0.0523 & 0.0482 \\
\hline PHX-7 & 132.51 & & & & & -0.0164 & & 0.0840 \\
\hline PHX-8 & 115.98 & & & & & -0.0141 & -0.0151 & \\
\hline
\end{tabular}


When a parallel heat exchanger is saturated (i.e. the heat available at a given temperature is higher than the maximum amount of heat that can be integrated in the corresponding PHX), the excess heat is valorized in the PHX situated right downstream.

In the case of heat integration into the preheaters 7 and 8 , attention should be paid on the evaluation of $Q_{P H X-i, \max }$ since this value depends on heat integrated into downstream preheaters. Indeed, if heat is integrated in preheaters $>6$, the steam flowrate to be reheated is modified.

Eventually, the procedure for heat integrated can be summarized as follows:

1. List all heat sources and sinks and sort them out according to temperature ranges of pre-heaters (and considered pinch) in order to obtain the values of $Q_{P H X-i, \text { available }}$, the remaining heat has to be evacuated into cooling water.

2. Evaluation of the maximum amount of heat that can be integrated into each preheaters

a. In the case of steam extraction (e.g. post-combustion), identify the reinjection point of steam condensate and calculate the extraction fraction using equation (9)

b. Calculate $Q_{P H X-i, \max }$ using equation(11) and $Q_{P H X-i, i n t e g}$ using equation (10), starting from the $8^{\text {th }}$ preheater down to the $1^{\text {st }}$ preheater.

c. If one of several preheaters are saturated (i.e. $Q_{P H X-i \text {,available }}>Q_{P H X-i \text { max }}$ ), report the surplus available heat into the downstream preheaters (if possible).

3. Calculate the equivalent electric power with equation (8)

In the case of $\mathrm{CO}_{2}$ capture, the specific energy penalty (in $\mathrm{kWh} / \mathrm{t}_{\mathrm{CO} 2}$ ) can be retrieved by dividing the equivalent electric power by the amount of captured $\mathrm{CO}_{2}$.

\subsection{Evaluation of $\mathrm{CO}_{2}$ compression work and compression waste heat duty}

In this study, the $\mathrm{CO}_{2}$ transport pressure considered in 110 bar. The number of compression stages is adjusted during the sensitivity analysis to keep the compression ratio close to 2 . The intercooling temperature can be either $42{ }^{\circ} \mathrm{C}$ so that the heat can be integrated in the first two preheaters of the steam cycle without using cooling water, or $28^{\circ} \mathrm{C}$ to perform an advanced cooling using cooling water. In a similar manner, the compression work and compression heat duty (which could be integrated in the feedwater preheaters) can be expressed as a function of the $\mathrm{CO}_{2}$ exiting the capture unit $P_{\text {capture }}$ :

$$
\begin{cases}w_{\text {compression }}\left[\mathrm{kWh} / \mathrm{t}_{\mathrm{CO} 2}\right] & =d_{0}+d_{1} \ln P_{\text {capture }} \\ q_{F W H-i}\left[\mathrm{GJ} / \mathrm{t}_{\mathrm{CO} 2}\right] & =e_{i}+f_{i} P_{\text {capture }}+g_{i} P_{\text {capture }}^{2} \quad i=1,2\end{cases}
$$

Where $P_{\text {capture }}$ is in bar. The coefficients are also reported in Table 7 and the Figure 7 compares the compression work of both intercooling temperatures.

Table 7 Coefficients of equations (11)(12)

\begin{tabular}{cccc}
\hline & Unit & $\begin{array}{c}\text { Intercooling } \\
\text { at } 42{ }^{\circ} \mathrm{C}\end{array}$ & $\begin{array}{c}\text { Intercooling } \\
\text { at } 28{ }^{\circ} \mathrm{C}\end{array}$ \\
\hline$d_{0}$ & $\mathrm{kWh} / \mathrm{t}_{\mathrm{CO} 2}$ & 101.283 & 95.824 \\
$d_{1}$ & $\mathrm{kWh} / \mathrm{t}_{\mathrm{CO} 2}$ & -26.389 & -26.135 \\
\hline$e_{1}$ & $\mathrm{GJ} / \mathrm{t}_{\mathrm{CO} 2}$ & 0.47041 & 0.35785 \\
$f_{1}$ & $\mathrm{GJ} / \mathrm{t}_{\mathrm{CO} 2} . \mathrm{bar}^{-1}$ & -0.13405 & -0.06517 \\
$g_{1}$ & $\mathrm{GJ} / \mathrm{t}_{\mathrm{CO} 2} \cdot \mathrm{bar}^{-2}$ & 0.01569 & 0.00619 \\
\hline$e_{2}$ & $\mathrm{GJ} / \mathrm{t}_{\mathrm{CO} 2}$ & 0.23404 & 0.11218 \\
$f_{2}$ & $\mathrm{GJ} / \mathrm{t}_{\mathrm{CO} 2}$. bar $^{-1}$ & -0.08260 & -0.06168 \\
$g_{2}$ & $\mathrm{GJ} / \mathrm{t}_{\mathrm{CO} 2 .}$. $^{-2}$ & 0.01148 & 0.00995 \\
\hline
\end{tabular}




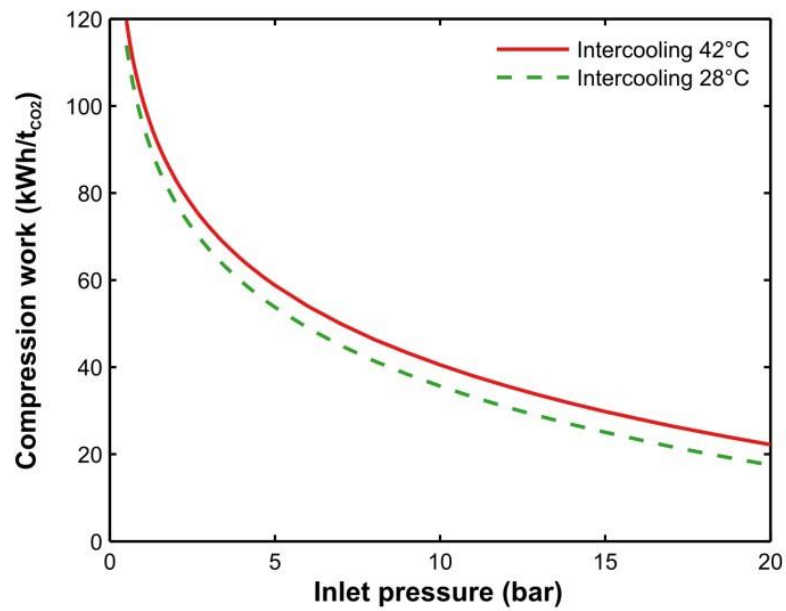

Figure 7 Comparison of compression work up to $\mathbf{1 1 0}$ bar for both intercooling temperatures

\subsection{Evaluation of miscellaneous auxiliaries consumption}

The auxiliaries work includes the electric consumption of compressors, fans and pumps. Theses work can be easily calculated from process parameters. Regarding the cooling water pumps, a rough evaluation of the pumps consumption can be performed using the expression proposed by [1] based on the heat duty to be evacuated into cooling water:

$$
w_{\text {pumps }, C W}\left[\mathrm{kWh} / \mathrm{t}_{\mathrm{CO} 2}\right]=Q_{C W}\left[\mathrm{GJ} / \mathrm{t}_{\mathrm{CO} 2}\right] \frac{\varphi_{C W}}{C_{P, C W} \Delta T_{C W}}
$$

where $w_{\text {pumps, } C W}$ is the electric consumption of cooling water pumps in $\mathrm{kWh} / \mathrm{t}_{\mathrm{CO} 2}, Q_{C W}$ the cooling heat duty (in $\mathrm{GJ} / \mathrm{t}_{\mathrm{CO} 2}$ ), $C_{P, C W}$ the heat capacity of water $\left.\left(C_{P, C W}=4.18410^{-3} \mathrm{GJ} . \mathrm{t}_{\mathrm{CW}}^{-1} \cdot \mathrm{K}^{-1}\right).\right), \Delta T_{C W}$ the temperature increase of cooling water (e.g. $10 \mathrm{~K})$ and $\varphi_{C W}$ the specific work of cooling water pumps $\left(\varphi_{C W}=107.83 \mathrm{kWh} / \mathrm{t}_{\mathrm{CW}}\right)$.

The cooling duty $Q_{C W}$ is the remaining heat that cannot be integrated into the feedwater preheaters, either due to low temperature levels, saturation of preheaters or by conception choice.

\section{Case study}

The presented procedure can be used to study the implementation of several technologies on the reference power plant. Illustrating examples are given in this section for post-combustion and oxy-combustion capture, heat and electricity cogeneration and hybridization.

\subsection{Post-combustion}

In this section, concrete examples are given to illustrate the use of the methodology presented herein and associated correlations in order to evaluate the full-scale impact of a post-combustion capture process on the electric production.

Post-combustion capture requires both thermal and electric energy to separate $\mathrm{CO}_{2}$ from the flue gas. In order to consider those different terms, the most practical way is to express the energy penalty in terms of equivalent work (in $\mathrm{kWh} / \mathrm{t}_{\mathrm{CO} 2}$ ), i.e. the production loss of the power plant, considering all energy consumptions.

This energy penalty can be decomposed into four terms:

$$
w_{\text {Capture_Post }}=w_{\text {Parastic }}+w_{\text {Compression }}+w_{\text {Aux }}-w_{\text {integ }}
$$

Where $w_{\text {Capture_Post }}$ is the energy penalty due to capture unit; $w_{\text {Parastic }}$ is the parasitic load, representing the production loss due to the steam extraction, which consider both vapor quantity (heat duty) and quality (vapor temperature); $w_{\text {Compression }}$ is the compression work to increase the $\mathrm{CO}_{2}$ from the capture pressure to the transport pressure; $w_{A u x}$ is the electrical work of the capture unit auxiliaries (e.g. fans, pumps, compressors); $w_{\text {integ }}$ is the energy saved by integration of residual heat of capture unit in the feedwater (see section 2.3 ).

Figure 9 shows the simplified flowsheet of the power plant equipped with post-combustion $\mathrm{CO}_{2}$ capture considered in this study, modeled using the same set of hypotheses as the air-fired power plant described in Section 2.1. In this process, a conventional amine process equipped with a flue gas polisher and a treated gas reheater is considered. The compression equipment in order to deliver the $\mathrm{CO}_{2}$ at 110 bar is also included. A $90 \% \mathrm{CO}_{2}$ capture efficiency has been considered. Table 8 shows the major hypotheses adopted for the post-combustion models.

Table 8 Major modeling hypotheses specific to the post-combustion power plant

Flue gas fan isentropic efficiency - 0.85

Flue gas path pressure drop

mbar 150




\begin{tabular}{lcc}
\hline Solvent pump isentropic efficiency & - & 0.75 \\
$\mathrm{CO}_{2}$ compressor isentropic efficiency & - & 0.85 \\
Compressor mechanical efficiency & - & 0.98 \\
Reboiler pinch & $\mathrm{K}$ & 10 \\
Condenser pinch & $\mathrm{K}$ & 10 \\
\hline
\end{tabular}

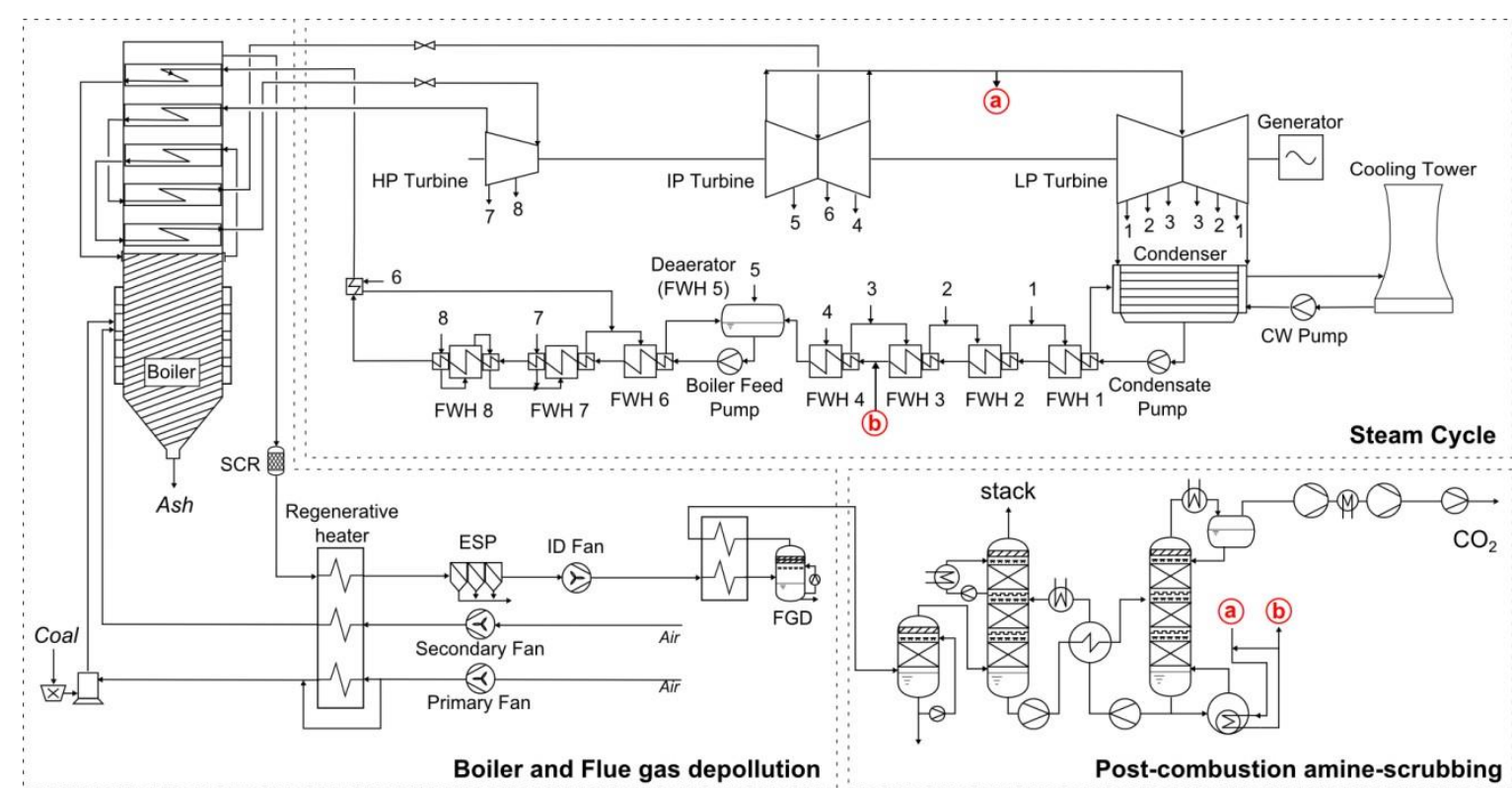

Figure 8 Simplified PFD of the base-case post-fired coal power plant

\section{Study of post-combustion processes}

With the developed correlations, a preliminary comparison of the pre-commercial $\mathrm{CO}_{2}$ capture processes available in open literature for both retrofit and new build power plant is made possible. Indeed, except for the auxiliaries work which strongly depends on the chosen capture process layout, all post combustion process can be mainly described in term of stripper condenser pressure, boiler temperature and quantity of needed steam; most of these information being available in open literature. However, whilst the specific reboiler duty is reported in all communications but the reboiler operating temperature and/or pressure is frequently overlooked.

The purpose of this section is not to compare processes but rather to illustrate the use of the correlations developed in the frame of the assessment methodology. Consequently, assumptions have been made to fill in the blanks in literature data. Regarding the stripper operating pressure, it is assumed that this pressure is directly linked to the quantity of produced $\mathrm{CO}_{2}$ and the stripper diameter; alternatively if the steam temperature or pressure is available a pinch of $10 \mathrm{~K}$ is assumed in the reboiler. The condenser inlet temperature has been set to $80 \%$ of the reboiler temperature and the condenser duty has been set to $180 \mathrm{kWh} / \mathrm{t}_{\mathrm{CO} 2}$ for MEA and adapted proportionally to the reboiler duty and condenser inlet temperature. The amount of cooling duty has been set as the sum of half the reboiler duty, the duty needed to cool the flue gas from 50 to $40{ }^{\circ} \mathrm{C}$ and the cooling duty of the $\mathrm{CO}_{2}$ compressor (i.e. adding $0.5 \mathrm{GJ} / \mathrm{t}$ to half of the reboiler duty) is not integrated. These assumptions, despite not being representative of a real unit behavior, provide satisfactory first-order estimation for missing data for a proper use of the correlations.

For auxiliaries, a power consumption of $20 \mathrm{kWh} / \mathrm{t}_{\mathrm{CO} 2}$ is assumed for a 50 meter high column for fan consumption; solvent circulation pumps power consumption is theoretically linked to columns height, column operating pressure and solvent flow rate. Without any information, a power consumption of $5 \mathrm{kWh} / \mathrm{t}_{\mathrm{cO} 2}$ is assumed for MEA and this figure has been adjusted proportionally for each process with respect to the L/G ratio. If the process features a lean vapor compression (LVC), for the base MEA case of CESAR project and the Fluor capture process, $25 \mathrm{kWh} / \mathrm{t}_{\mathrm{CO} 2}$ is added, a typical value near the optimum performance of LVC.

The Table 9 summarizes the data gathered in literature as well as the values extrapolated from the data for the power plant performance assessment. 
Table 9 Data of the different post-combustion process evaluated (in black: value taken from reference 1: [12], 2: [13], 3: [14], 4: [15], 5: [16], 6: [17], 7: [10]; in italic grey: estimated value)

\begin{tabular}{lccccccccc}
\hline Supplier & - & $\begin{array}{c}\text { CESAR } \\
\text { project }\end{array}$ & $\begin{array}{c}\text { CESAR } \\
\text { project }\end{array}$ & Fluor & MHI & $\begin{array}{c}\text { Alstom- } \\
\text { Dow }\end{array}$ & $\begin{array}{c}\text { Babcock } \\
\text {-Hitachi }\end{array}$ & $\begin{array}{c}\text { Doosan- } \\
\text { HTC }\end{array}$ & $\begin{array}{c}\text { Linde- } \\
\text { BASF }\end{array}$ \\
\hline Solvent & - & MEA & AMP/PZ & MEA & KS-1 & $\begin{array}{c}\text { UCARSOL } \\
3000\end{array}$ & H3 & RS-2 & OASE-Blue \\
Process & - & LVC & ICA & LVC, ICA & Prop. & Prop. & Prop. & Prop. & Prop. \\
\hline Capacity & $\mathrm{t} / \mathrm{h}$ & 1.0 & 1.0 & - & - & 1.04 & - & 4.2 & - \\
Stripper D. & $\mathrm{m}$ & 0.75 & 0.75 & - & - & 0.60 & - & 1.1 & - \\
Stripper P. & $\mathrm{bar}$ & 1.85 & 1.85 & 2.0 & 1.6 & 3.0 & 1.8 & 3.6 & 3.5 \\
\hline Reboiler T. & ${ }^{\circ} \mathrm{C}$ & 120 & 120 & 125 & 120 & 130 & 120 & 135 & 135 \\
L/G & - & 3.0 & 2.0 & 3.0 & 1.0 & 3.0 & 2.0 & 3.0 & 3.0 \\
\hline Aux. Pump & $\mathrm{kWh/t}$ & 5 & 3.2 & 5 & 1.6 & 5 & 3.2 & 5 & 5 \\
Aux. Process & $\mathrm{kWh/t}$ & 25 & 0 & 25 & 0 & 0 & 0 & 0 & 0 \\
Aux. Fan & $\mathrm{kWh/t}$ & 20 & 20 & 20 & 20 & 20 & 20 & 20 & 20 \\
\hline Reboiler duty & $\mathrm{GJ} / \mathrm{t}$ & 2.90 & 2.80 & 2.85 & 2.45 & 2.30 & 2.60 & 2.40 & 2.40 \\
Cooling duty & $\mathrm{GJ} / \mathrm{t}$ & 1.95 & 1.90 & 1.93 & 1.73 & 1.65 & 1.80 & 1.70 & 1.70 \\
\hline Reference & - & 1 & 1 & 2 & 3 & 4 & 5 & 6 & 7 \\
\hline
\end{tabular}

Investigated integration configurations

Several integration strategies can be considered to couple an amine post-combustion process to a power plant. Five different power plant / capture plant integration options have been evaluated ranking from a basic retrofit to an advanced integration for newly built power plant. The five options are:

- Case 1, retrofit with minimal integration: the steam is extracted at the crossover pipe at 8.9 bar, a throttle valve reduced its pressure in order to have the right condensation temperature, the steam is desuperheated by mixing with the reboiler condensate. This condensate is sent back to the feedwater preheaters train at the right temperature. No capture plant waste heat is integrated in the steam cycle. A conservative pinch of $10 \mathrm{~K}$ is assumed for both reboiler and condenser.

- Case 2, retrofit with heat integration: as for the case 1 but the capture plant waste heat, from the stripper condenser and the compression train, is integrated at the appropriate level in the steam cycle.

- Case 3, retrofit with heat integration and additional expansion turbine: as for the case 2 but the pressure of the extracted steam is adjusted by expansion through an additional steam turbine (with $75 \%$ isentropic efficiency).

- Case 4, new build with heat integration: the steam is extracted at the crossover pipe directly at the appropriate pressure for the reboiler the steam is desuperheated by direct mixing with the reboiler condensate. This condensate is sent back to the feedwater preheaters train at the most appropriated temperature. The capture plant waste heat, from the stripper condenser and the compression train, is integrated at the appropriate level in the steam cycle. A conservative pinch of $10 \mathrm{~K}$ is assumed for both reboiler and condenser.

- Case 5, new build with advanced heat integration: similar to case 4 but the extracted steam is desuperheated by indirect heat exchange with the reboiler condensate and a pinch of $5 \mathrm{~K}$ is assumed for both reboiler and condenser.

The power plant integration results are presented in Table 10 for the different processes detailed in Table 9 and for the five integration strategies. Once again, the sole purpose is to illustrate the generic assessment methodology instead of ranking different processes. For each process and integration strategy are reported the contribution of total energy penalty: parasitic, compression, auxiliaries and cooling water pumps works as well as the heat integration savings.

Case 1 to case 2: it can be seen that integrating the residual heat of capture unit into the feedwater preheaters has a significant effect on energy penalty, reducing the efficiency loss by approximately $0.6 \%$-pts.

Case 2 to case 3: the use of an expansion turbine instead of a valve for the pressure adaptation of steam considerably reduces the energy penalty by 0.5 to $1.2 \%$-pts due to the electric production of the turbine.

Case 3 to case 4: similarly for the new build case, the design of expansion turbines so that the crossover pipe is at the proper pressure allows benefiting from the high IP turbine efficiency, increasing again the energy savings by 0.3 to $0.5 \%$-pts (compared to expansion turbine with $75 \%$ efficiency).

Case 4 to case 5: additionally, the indirect steam desuperheating instead of direct mixing reduces the efficiency loss by approximately $0.2 \%$-pts. 
The major improvement is obviously the steam expansion in a turbine instead of a valve but this comparison has stressed out that heat integration and desuperheating strategy can also significantly improve the overall performance.

The parasitic load is mainly a function of the reboiler temperature (heat quality) and heat duty (heat quantity) and its value increases with both variables. An increase of stripper pressure, and consequently of reboiler temperature, leading to a decrease of reboiler heat duty, the parasitic load allows a rigorous comparison of energy demand, including both heat quality and quantity. An interesting aspect of thermal integration with power plant is the relative impact of temperature and heat duty according to the chosen integration strategy. For a basic integration with an expansion valve (e.g. cases 1 and 2), the temperature effect has a small influence on parasitic load, whereas the significance is higher with an expansion turbine (e.g. case 3). For example, the ' $\mathrm{MHI}$ ' and 'Doosan-HTC' processes have respectively reboiler heat duties of 2.45 and $2.40 \mathrm{GJ} / \mathrm{t}$ and reboiler temperatures of $120^{\circ} \mathrm{C}$ and $135^{\circ} \mathrm{C}$. For the cases 1 and 2, the 'MHI' parasitic load $(187 \mathrm{kWh} / \mathrm{t})$ is higher than the 'Doosan-HTC' one (183 kWh/t) due to a higher heat duty despite a lower temperature. While the situation is inverted for the case 3 (respectively 149 and $159 \mathrm{kWh} / \mathrm{t}$ for ' $\mathrm{MHI}$ ' and 'Doosan-HTC' processes), a lower temperature is preferable with a better heat integration between reboiler and power plant.

As outlined above, the reboiler heat duty is not a proper indicator since the corresponding temperature plays an important role on parasitic load, especially for new-build cases. Furthermore, this value can be decreased using vapor recompressor (e.g. Lean Vapor Compression) but at the cost of additional mechanical work, hence a need for an overall estimation at powerplant scale.

Finally, the first key message of this basis comparison is the importance of considering all process parameters for a conclusive evaluation of energy performance, including all thermal (quality as well as quantity) and electric requirements. Also, an advanced integration strategy between capture unit and steam cycle is as important as the development of new processes and solvents. This point is illustrated in Table 10, shifting the process and solvent allows a gain between 5 and $80 \mathrm{kWh} / \mathrm{t}(0.2$ to $2.7 \%$-pts) whereas using an advanced integration reduces the energy penalty by 55 to $80 \mathrm{kWh} / \mathrm{t}$ (1.7 to $2.6 \%$-pts).

Table 10 Results of reference power plant efficiency losses for the investigated post-combustion processes and the 5 integration cases

\begin{tabular}{|c|c|c|c|c|c|c|c|c|c|}
\hline Supplier & - & $\begin{array}{l}\text { CESAR } \\
\text { project }\end{array}$ & $\begin{array}{l}\text { CESAR } \\
\text { project }\end{array}$ & Fluor & $\mathrm{MHI}$ & $\begin{array}{c}\text { Alstom- } \\
\text { Dow }\end{array}$ & $\begin{array}{c}\text { Babcock- } \\
\text { Hitachi }\end{array}$ & $\begin{array}{c}\text { Doosan- } \\
\text { HTC }\end{array}$ & $\begin{array}{l}\text { Linde- } \\
\text { BASF }\end{array}$ \\
\hline \multicolumn{10}{|c|}{ Case 1: Retrofit, $10 \mathrm{~K}$ pinch in reboiler \& condenser, no expansion turbine, direct desuperheating, no heat integration } \\
\hline Parasitic load & $\mathrm{kWh} / \mathrm{t}$ & 220.9 & 213.3 & 217.3 & 186.6 & 175.4 & 198.0 & 183.1 & 183.1 \\
\hline Compression & $\mathrm{kWh} / \mathrm{t}$ & 85.0 & 85.0 & 83.0 & 88.9 & 72.3 & 85.8 & 67.5 & 68.2 \\
\hline Auxiliaries & $\mathrm{kWh} / \mathrm{t}$ & 50.0 & 23.0 & 50.0 & 22.0 & 25.0 & 23.0 & 25.0 & 25.0 \\
\hline Cooling & $\mathrm{kWh} / \mathrm{t}$ & 5.0 & 4.9 & 5.0 & 4.5 & 4.3 & 4.6 & 4.4 & 4.4 \\
\hline Total & $\mathrm{kWh} / \mathrm{t}$ & 356.5 & 321.7 & 350.8 & 297.1 & 272.3 & 306.8 & 275.6 & 276.4 \\
\hline Efficiency loss & $\%$-pts & 11.1 & 10.0 & 10.9 & 9.2 & 8.5 & 9.5 & 8.6 & 8.6 \\
\hline Net efficiency & $\%$ LHV & 35.0 & 36.1 & 35.2 & 36.9 & 37.7 & 36.6 & 37.6 & 37.5 \\
\hline \multicolumn{10}{|c|}{ Case 2: Retrofit, $10 \mathrm{~K}$ pinch in reboiler \& condenser, no expansion turbine, direct desuperheating, heat integration } \\
\hline Parasitic load & $\mathrm{kWh} / \mathrm{t}$ & 220.9 & 213.3 & 217.3 & 186.6 & 175.4 & 198.0 & 183.1 & 183.1 \\
\hline Compression & $\mathrm{kWh} / \mathrm{t}$ & 79.7 & 79.7 & 77.7 & 83.5 & 67.1 & 80.5 & 62.3 & 63.1 \\
\hline Auxiliaries & $\mathrm{kWh} / \mathrm{t}$ & 50.0 & 23.0 & 50.0 & 22.0 & 25.0 & 23.0 & 25.0 & 25.0 \\
\hline Cooling & $\mathrm{kWh} / \mathrm{t}$ & 5.8 & 5.6 & 5.9 & 5.0 & 4.8 & 5.2 & 5.2 & 5.2 \\
\hline Integration & $\mathrm{kWh} / \mathrm{t}$ & -7.9 & -8.0 & -8.0 & -8.2 & -8.3 & -8.1 & -8.2 & -8.2 \\
\hline Total & $\mathrm{kWh} / \mathrm{t}$ & 348.5 & 313.6 & 342.9 & 288.9 & 264.0 & 298.6 & 267.4 & 268.1 \\
\hline Efficiency loss & $\%$-pts & 10.8 & 9.8 & 10.7 & 9.0 & 8.2 & 9.3 & 8.3 & 8.3 \\
\hline Net efficiency & \%LHV & 35.3 & 36.4 & 35.5 & 37.2 & 37.9 & 36.8 & 37.8 & 37.8 \\
\hline \multicolumn{10}{|c|}{ Case 3: Retrofit, $10 \mathrm{~K}$ pinch in reboiler \& condenser, expansion turbine $(n=75 \%)$, direct desuperheating, heat integration } \\
\hline Parasitic load & $\mathrm{kWh} / \mathrm{t}$ & 176.8 & 170.8 & 178.8 & 149.5 & 146.0 & 158.6 & 159.3 & 159.3 \\
\hline Compression & $\mathrm{kWh} / \mathrm{t}$ & 79.7 & 79.7 & 77.7 & 83.5 & 67.1 & 80.5 & 62.3 & 63.1 \\
\hline Auxiliaries & $\mathrm{kWh} / \mathrm{t}$ & 50.0 & 23.0 & 50.0 & 22.0 & 25.0 & 23.0 & 25.0 & 25.0 \\
\hline Cooling & $\mathrm{kWh} / \mathrm{t}$ & 5.9 & 5.7 & 5.9 & 5.0 & 4.8 & 5.3 & 5.2 & 5.2 \\
\hline Integration & $\mathrm{kWh} / \mathrm{t}$ & -7.7 & -7.7 & -7.7 & -8.0 & -8.1 & -7.9 & -8.0 & -8.0 \\
\hline Total & $\mathrm{kWh} / \mathrm{t}$ & 304.8 & 271.4 & 304.7 & 252.0 & 234.9 & 259.4 & 243.8 & 244.5 \\
\hline Efficiency loss & $\%$-pts & 9.5 & 8.4 & 9.5 & 7.8 & 7.3 & 8.1 & 7.6 & 7.6 \\
\hline Net efficiency & $\%$ LHV & 36.7 & 37.7 & 36.7 & 38.3 & 38.8 & 38.1 & 38.6 & 38.5 \\
\hline
\end{tabular}




\begin{tabular}{|c|c|c|c|c|c|c|c|c|c|}
\hline Parasitic load & $\mathrm{kWh} / \mathrm{t}$ & 163.2 & 157.6 & 166.9 & 137.9 & 136.9 & 146.4 & 151.8 & 151.8 \\
\hline Compression & $\mathrm{kWh} / \mathrm{t}$ & 79.7 & 79.7 & 77.7 & 83.5 & 67.1 & 80.5 & 62.3 & 63.1 \\
\hline Auxiliaries & $\mathrm{kWh} / \mathrm{t}$ & 50.0 & 23.0 & 50.0 & 22.0 & 25.0 & 23.0 & 25.0 & 25.0 \\
\hline Cooling & $\mathrm{kWh} / \mathrm{t}$ & 5.9 & 5.7 & 5.9 & 5.0 & 4.8 & 5.3 & 5.2 & 5.2 \\
\hline Integration & $\mathrm{kWh} / \mathrm{t}$ & -7.7 & -7.7 & -7.7 & -8.0 & -8.1 & -7.9 & -8.0 & -8.0 \\
\hline Total & $\mathrm{kWh} / \mathrm{t}$ & 291.1 & 258.3 & 292.8 & 240.5 & 225.7 & 247.2 & 236.3 & 237.1 \\
\hline Efficiency loss & \%-pts & 9.1 & 8.0 & 9.1 & 7.5 & 7.0 & 7.7 & 7.4 & 7.4 \\
\hline Net efficiency & $\% L H V$ & 37.1 & 38.1 & 37.0 & 38.7 & 39.1 & 38.4 & 38.8 & 38.8 \\
\hline \multicolumn{10}{|c|}{ Case 5: New build, $5 \mathrm{~K}$ pinch in reboiler \& condenser, indirect desuperheating, heat integration } \\
\hline Parasitic load & $\mathrm{kWh} / \mathrm{t}$ & 153.8 & 148.5 & 157.3 & 130.0 & 129.0 & 137.9 & 143.0 & 143.0 \\
\hline Compression & $\mathrm{kWh} / \mathrm{t}$ & 79.7 & 79.7 & 77.7 & 83.5 & 67.1 & 80.5 & 62.3 & 63.1 \\
\hline Auxiliaries & $\mathrm{kWh} / \mathrm{t}$ & 50.0 & 23.0 & 50.0 & 22.0 & 25.0 & 23.0 & 25.0 & 25.0 \\
\hline Cooling & $\mathrm{kWh} / \mathrm{t}$ & 5.9 & 5.7 & 5.9 & 5.0 & 4.8 & 5.3 & 5.2 & 5.2 \\
\hline Integration & $\mathrm{kWh} / \mathrm{t}$ & -7.6 & -7.7 & -7.6 & -8.0 & -8.1 & -7.9 & -8.0 & -8.0 \\
\hline Total & $\mathrm{kWh} / \mathrm{t}$ & 281.8 & 249.2 & 283.2 & 232.6 & 217.9 & 238.8 & 227.6 & 228.3 \\
\hline Efficiency loss & $\%$-pts & 8.8 & 7.8 & 8.8 & 7.2 & 6.8 & 7.4 & 7.1 & 7.1 \\
\hline Net efficiency & $\%_{\text {LHV }}$ & 37.4 & 38.4 & 37.3 & 38.9 & 39.4 & 38.7 & 39.1 & 39.0 \\
\hline
\end{tabular}

\subsection{Oxy-combustion}

Unlike post-combustion capture, oxy-combustion implies structural changes of the boiler island: flue gas and oxidant flows compositions, temperatures and flowrates are modified which directly impacts the heat transfer characteristics to the steam cycle and the auxiliaries' consumptions. Indeed, for a given coal input and combustive flows boiler inlet temperatures, the reduced flue gas flowrate in oxy-firing compared to air-firing and the composition differences lead to a different amount of total distribution between radiative and convective heat inducing a modification in the gross turbine production. Concerning the auxiliaries consumption in oxy-combustion, in addition to the power consumption associated to the ASU, the CPU and some units required for operation in oxy-combustion such as a direct contact cooler polishing scrubber (DCCPS) and a flue gas reheater (FG reheater), the structural modification of the flue gas train induces variation of several auxiliaries consumption. For instance, the flue gas flowrate reduction results in a decrease of the fan consumption (-60\%). The wet FGD consumption, strongly linked to the slurry pumping power requirement, is also modified due to the reduction of the flowrate to be treated and the increased inlet $\mathrm{SO}_{2}$ concentration. The additional consumption induced by the capture of the $\mathrm{CO}_{2}$ in oxy-combustion ( $\left.W_{\text {Capture_oxy }}\right)$ is expressed as followings:

$$
W_{\text {Capture_oxy }}=\Delta W_{\text {Turbine }}+\Delta W_{\text {Aux }}+W_{A S U}+W_{C P U}
$$

where $\Delta W_{\text {turbine }}$ and $\Delta W_{\text {aux }}$ are respectively the gross turbine output and the auxiliaries consumption differences between aircombustion and oxy-combustion; $W_{A S U}$ the ASU power consumption and $W_{C P U}$ the CPU one which includes the $\mathrm{CO}_{2}$ compression work up to pipeline specifications.

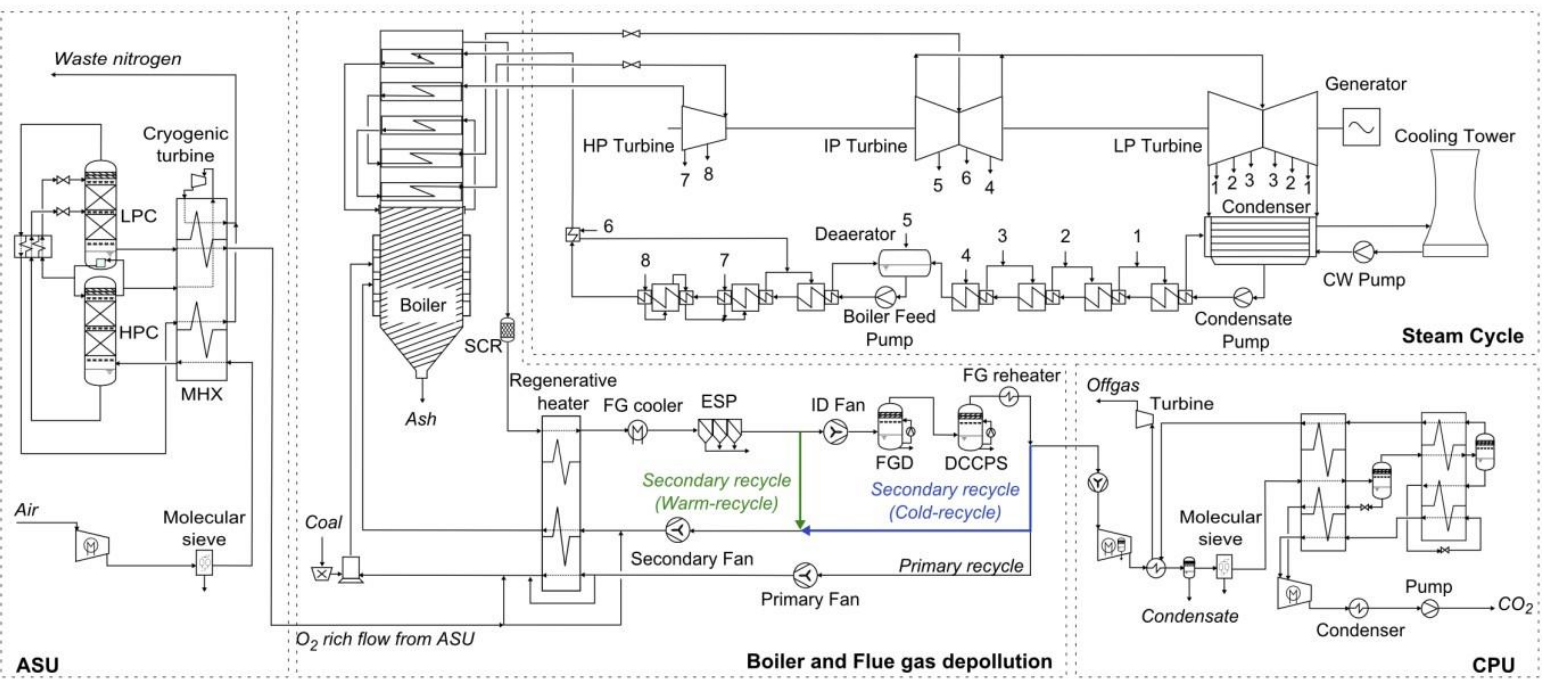

Figure 9 Simplified PFD of the base-case oxy-fired coal power plant 
Figure 9 shows the simplified flowsheet of the base-case oxy-fired power plant considered in this study, modeled using the same set of hypotheses as the air-fired power plant described in Section 2.1. In this process, a conventional cryogenic doublecolumn air separation process providing an $95 \%$ mol oxygen flow at 1.2 bar is considered and the $\mathrm{CO}_{2}$ enriched flue gas is purified by partial condensation up to $96 \%$ mol in a double-flash process and compressed up to 110 bar for further pipeline transportation. The recovery rate of the CPU is $90 \%$. Table 11 summarizes the major hypotheses adopted for the oxycombustion models.

\begin{tabular}{lcc} 
Table 11 Major modeling hypotheses specific to the oxy-combustion power plant \\
\hline Air compressor isentropic efficiency (ASU) & - & 0.87 \\
Flue gas $/ \mathrm{CO}_{2}$ compressor isentropic efficiency (CPU) & - & 0.85 \\
Compressor mechanical efficiency & - & 0.98 \\
ASU and CPU cryogenic heat exchanger pinch & $\mathrm{K}$ & 1.5 \\
ASU condenser-reboiler pinch & $\mathrm{K}$ & 1 \\
Total air infiltration & $\%_{\mathrm{wt}}$ & 3 \\
Wet FGD L/G ratio (cold-recycle/warm-recycle) & $\mathrm{kg} / \mathrm{Nm}^{3}$ & $17 / 29$ \\
\hline
\end{tabular}

Concerning the flue gas treatment, the same layout as air combustion is employed, to which is added a DCCPS further reducing the $\mathrm{SO}_{x}$ concentration and the moisture content of the flue gas by saturating at $18.5^{\circ} \mathrm{C}$. The flue gas is then slightly reheated in an electric heater (up to $40^{\circ} \mathrm{C}$ ) in order to avoid any downstream condensation. In oxy-combustion, the flue gas regenerative heater outlet temperature being higher than air-combustion, a flue gas cooler is placed to reduce the temperature down to $130^{\circ} \mathrm{C}$.

\section{Study of oxy-combustion processes}

Oxy-combustion power plant required new equipments such as ASU and CPU but also a major revamp of the air and flue gas paths. In this study, two flue gas recycle options and three different ASU processes have been considered.

As highlighted by [18], oxy-combustion offers different flue gas recycle options. In this study, the two most common layouts are considered: cold-recycle in which both the primary and secondary recycles are fully depolluted and warm-recycle in which the secondary recycle is realized before desulfurization and therefore at higher temperature. The modification of the position of the secondary recycle also impacts the recycle rate since the oxygen partial pressure at boiler inlet has to be reduced from 0.35 down to 0.28 to obtain air-like combustion characteristics with a higher moisture content due to the recycling before the DCCPS. Otherwise, warm-recycle allows reducing the flue gas flowrate heading the downstream depollution equipments. Two advanced ASU architectures have been considered in addition of the conventional ASU considered in the base-case. These ASU, proposed by technology providers 'Air Liquide' [19] and 'Air Products' [20] aim at reducing specific consumptions. The power consumption of an ASU being due to the compression of air, the advanced ASU with improved energy performances all have lower air compression ratio, which also implies a reduced amount of compression heat available for integration. Thus, the gains brought by the heat integration have to be assessed independently for each ASU architecture. Indeed, for a given ASU or CPU architecture, if standalone minimization of the energy consumption is desired, stagedcompression with intermediate cooling with cooling water leads to the best performance due to the lack of sufficient heat sink in the process. However, if those processes are considered as part of the power plant, the valorization of the compression heat becomes possible and the resort to adiabatic compression needs to be assessed. The integration of the ASU, for both intercooled and adiabatic compression, is realized for the warm-recycle scheme with the integration of the FG bypass surplus heat and the preheating of the oxygen flow (Case 4 defined below).

Investigated integration configurations

Several heat integration strategies can be considered for an oxy-fired power plant, in this study four are investigated:

- $\quad$ Case 1, retrofit with minimal integration: no waste heat integration, electric flue gas reheating.

- Case 2, retrofit with heat integration: waste heat integration in the steam cycle, steam flue gas reheating and flue gas heat valorization through a standard regenerative heat exchanger followed by another heat exchanger.

- Case 3, new build with heat integration: waste heat integration in the steam cycle, steam flue gas reheating and flue gas heat valorization through a standard regenerative heat exchanger and a flue gas bypass heat exchanger.

- $\quad$ Case 4 : similar to case 3 with steam oxygen preheating

In order to quantify the amount of heat to be integrated for cases 2 to 4 , a detailed inventory of heat sources needs to be carried out. First of all, large amounts of heat are dissipated during the intercooling steps of the ASU and CPU staged compressions. However, the heat being available at low temperature, the efficient valorization of the thermal exergy is impossible due to the saturation of the first parallel heat exchanger (PHX-1). Thus, in order to maximize the overall exergy efficiency, adiabatic compression is adopted instead of staged compression because despite the additional compression power requirement, the increase of the compressor outlet temperature allows the valorization of the totality of the heat duty. The flue gas compressor at the CPU inlet has been modeled as two adiabatic compressors in order to keep a realistic pressure ratio and moderate the temperature increase. In the base-case plant, the CPU offgas flow is reheated during 
expansion by the compression heat. Assuming the integration of the compression heat into the steam cycle, heat has to be provided by the steam cycle in order to ensure that no $\mathrm{CO}_{2}$ freezing occurs. The reheat of the flue gas after the DCCPS, realized in an electric heater in the base-case, can be realized using a material flow at the adequate temperature level in order to minimize the exergy losses. Last but not least, the flue gas heat $\left(\mathrm{Q}_{\mathrm{FG}}\right)$ dissipated in the flue gas cooler in case 1 can be used as a heat source. Indeed, the higher temperature of the recycle flows at the regenerative heater cold-end in oxy-combustion induces a significant increase of the flue gas cold-end temperature. In case 2, this additional heat is recovered in the FG cooler. However, in cases 3 and 4, in order to reduce the irreversibilities induced by the large temperature difference in the heat exchanger, it is possible to bypass a portion of the hot flue gas upstream the regenerative heater to recover a high temperature heat in a dedicated heat exchanger so called "FG bypass surplus heat recovery exchanger". Finally, for the cases 1 to 3 , the oxygen flow from the ASU, delivered at $23^{\circ} \mathrm{C}$, is mixed to the recycle flows without preheating, which induces a temperature drop. The case 4 includes the preheating of the oxygen flow at the adequate temperature before mixing to the recycle flows in order to avoid this exergy destruction and further reduce the exergy losses in the regenerative heater.

In oxy-combustion, the modification of the boiler section leads to a slight variation of the heat transfer to the steam cycle. Thus, a verification of the validity of the marginal efficiencies derived from the air-fired plant is necessary and for that matter, the NPE obtained by the calculation and the ones provided by the simulation have been compared. Those values lead to relative deviations of $0.02 \%$ and $0.01 \%$ respectively for cold-recycle and warm-recycle cases, which is satisfactory.

The oxy-fired power plant integration results are presented in Table 12 for the standard double-column ASU considered in the base-case and the two alternative low-consumptions proposed by 'Air Liquide' and 'Air Products', cold-recycle and warmrecycle and for the four integration cases described above. For each case, the contribution of the ASU and the CPU along with the gross power output difference with the air-fired case due to oxy-firing ( $\Delta$ Turbine) as well as the auxiliaries consumption difference ( $\triangle$ Auxiliaries). This last figure takes into account: the main power consumption difference between air and oxyfiring, naming the flue gas fan and the FGD slurry pump; the consumption of additional auxiliaries such as the DCCPS circulation pump and the electric heater; and finally the additional pumping power requirement related to the increased cooling water demand necessary to evacuate the process waste heat (intercooling of the compressions and flue gas heat evaluation for case 1). For clarification purpose, it has to be stressed that the ASU specific energy figures displayed in Table 12 are relative to the captured $\mathrm{CO}_{2}\left(\mathrm{kWh} / \mathrm{t}_{\mathrm{CO} 2}\right)$ and not to the produced oxygen $\left(\mathrm{kWh} / \mathrm{t}_{\mathrm{O} 2}\right)$.

Case 1: in this retrofit case, staged compression with intercooling have been considered for the CPU compression steps since it minimizes the standalone power consumption. This effect is also reflected when the comparison of the ASU consumption between the adiabatic case and the intercooled case is made. Indeed, for all the three considered ASU, staged compression with intercooling systematically leads to the lower energy penalty. When no thermal integration is performed, the 'Air Products' ASU leads to the lowest energy penalty, reducing the energy penalty by approximately $1.9 \%$-pts compared to the standard double-column ASU.

Case 2 to case 4: for those three cases, the auxiliaries' consumption difference, which had positive value for Case 1 , is negative after integration because of the use of heat from PHX-1 as heat source instead of electricity for the reheating of the flue gas after the DCCPS. Another factor contributing to the reduction of the auxiliaries' consumption, to a lesser extent, is the reduction of the cooling water pumping power resulting of the valorization of heat sources into the steam cycle. The increase in the CPU contribution to the energy penalty is due to the substitution of staged compressions by adiabatic compressions to increase the overall system efficiency.

The comparison of the energy penalties of the three integration cases at constant ASU configuration shows that Case 4 systematically leads to the best performances. For both cold and warm recycle, the flue gas heat duty is better valorized by the means of a bypass and the preheating of the oxygen flows coming from the ASU further increases this gain because of both the increased temperature level at which the heat source is integrated and the reduced exergy losses in the regenerative heater. Additionally, the shifting of the flue gas duty recovery temperature towards higher temperature (Case 3 and 4 ) allows not downgrading heat to lower levels. This is observed for the warm-recycle scheme involving the 'Air Liquide' ASU's adiabatic compression heat integration. In Case 2, PHX-3 is saturated due to the large share of the flue gas heat available at this temperature level, leading to the necessity to downgrade 4.8 $\mathrm{MW}_{\text {th }}$ from PHX-3 to PHX-2, leading to a slight reduction of the integration gain. While not being particularly relevant in that particular case, this example highlights the importance of the simultaneous consideration of all the heat sources and the available heat sinks when the assessment of the improvement potential of global system energy by thermal integration is targeted.

When heat integration is performed, adiabatic compression shows better performance than intercooled compression. This is due to the fact that, for the low-consumption ASU, the temperatures of the heat duties available at the compressors' intercoolers (when staged compression is performed) are not high enough to be integrated in the steam cycle. Concerning the standard ASU, despite the temperature being compatible for integration in PHX-1, the valorization of the compression heat is limited by the saturation of PHX-1. Another interesting point is that, because of the compression layout differences, the 'Air Liquide' ASU leads to slightly better performances than 'Air Products' one when thermal integration is performed. This difference is due to both the difference in available heat duty (quantity) and their temperature level (quality). 
As for the post-combustion capture case studies, the aim of this paper is not to state whether the technology provided by a vendor is better than another or not but to compare on a consistent basis, using process parameters, different technologies and process layouts in order to identify the improvement potential of the oxy-combustion $\mathrm{CO}_{2}$ capture system. Finally, for more detailed descriptions and discussions about the flue gas recycle schemes, flue gas heat integration or advanced ASUs flow-schemes, please refer to [21].

Table 12 Results of the investigated oxy-combustion processes layouts and the 4 integration cases

\begin{tabular}{|c|c|c|c|c|c|c|c|c|c|}
\hline Recycle & & Cold & Cold & Warm & Warm & Warm & Warm & Warm & Warm \\
\hline ASU & & Standard & Standard & Standard & Standard & Air Liquide & Air Liquide & $\begin{array}{l}\text { Air } \\
\text { Products }\end{array}$ & $\begin{array}{c}\text { Air } \\
\text { Products }\end{array}$ \\
\hline ASU compressor & & Adiabatic & Intercooled & Adiabatic & Intercooled & Adiabatic & Intercooled & Adiabatic & Intercooled \\
\hline \multicolumn{10}{|c|}{ Case 1: Retrofit, no heat integration, no $\mathrm{O}_{2}$ preheating } \\
\hline ASU & $\mathrm{kWh} / \mathrm{t}$ & 215.7 & 189.3 & 216.7 & 190.3 & 178.4 & 162.9 & 172.0 & 160.6 \\
\hline CPU & $\mathrm{kWh} / \mathrm{t}$ & 113.1 & 113.1 & 115.5 & 115.5 & 115.5 & 115.5 & 115.5 & 115.5 \\
\hline$\Delta$ Turbine & $\mathrm{kWh} / \mathrm{t}$ & -7.4 & -7.4 & -2.3 & -2.3 & -2.3 & -2.3 & -2.3 & -2.3 \\
\hline$\Delta$ Auxiliaries & $\mathrm{kWh} / \mathrm{t}$ & 16.6 & 16.4 & 9.1 & 8.9 & 8.6 & 8.6 & 8.7 & 8.6 \\
\hline$\Delta$ Fan & $\mathrm{kWh} / \mathrm{t}$ & -11.0 & -11.0 & -11.0 & -11.0 & -11.0 & -11.0 & -11.0 & -11.0 \\
\hline$\Delta \mathrm{FGD}$ & $\mathrm{kWh} / \mathrm{t}$ & -0.7 & -0.7 & 1.0 & 1.0 & 1.0 & 1.0 & 1.0 & 1.0 \\
\hline DCCPS & $\mathrm{kWh} / \mathrm{t}$ & 5.8 & 5.8 & 4.1 & 4.1 & 4.1 & 4.1 & 4.1 & 4.1 \\
\hline FG reheater & $\mathrm{kWh} / \mathrm{t}$ & 19.5 & 19.5 & 11.5 & 11.5 & 11.5 & 11.5 & 11.5 & 11.5 \\
\hline Cooling & $\mathrm{kWh} / \mathrm{t}$ & 3.0 & 2.8 & 3.5 & 3.3 & 3.0 & 3.0 & 3.1 & 3.0 \\
\hline Total & $\mathrm{kWh} / \mathrm{t}$ & 338.0 & 311.4 & 339.0 & 312.4 & 297.2 & 281.7 & 290.8 & 279.4 \\
\hline Efficiency loss & \%-pts & 10.5 & 9.6 & 10.5 & 9.7 & 9.2 & 8.7 & 9.0 & 8.6 \\
\hline Net efficiency & \% LHV & 35.6 & 36.5 & 35.6 & 36.4 & 36.9 & 37.4 & 37.1 & 37.5 \\
\hline \multicolumn{10}{|c|}{ Case 2: Retrofit, flue gas cooler, heat integration, no $\mathrm{O}_{2}$ preheating } \\
\hline ASU & $\mathrm{kWh} / \mathrm{t}$ & 215.7 & 189.3 & 216.7 & 190.3 & 178.4 & 162.9 & 172.0 & 160.6 \\
\hline CPU & $\mathrm{kWh} / \mathrm{t}$ & 132.3 & 132.3 & 134.7 & 134.7 & 134.7 & 134.7 & 134.7 & 134.7 \\
\hline$\Delta$ Turbine & $\mathrm{kWh} / \mathrm{t}$ & -7.4 & -7.4 & -2.3 & -2.3 & -2.3 & -2.3 & -2.3 & -2.3 \\
\hline$\Delta$ Auxiliaries & $\mathrm{kWh} / \mathrm{t}$ & -3.5 & -3.2 & -6.5 & -6.1 & -6.3 & -5.6 & -6.2 & -5.6 \\
\hline Integration & $\mathrm{kWh} / \mathrm{t}$ & -71.6 & -44.2 & -89.0 & -56.8 & -69.3 & -47.1 & -62.2 & -47.1 \\
\hline Total & $\mathrm{kWh} / \mathrm{t}$ & 265.6 & 266.9 & 253.6 & 259.8 & 235.2 & 242.6 & 236.0 & 240.3 \\
\hline Efficiency loss & $\%$-pts & 8.2 & 8.3 & 7.9 & 8.0 & 7.3 & 7.5 & 7.3 & 7.4 \\
\hline Net efficiency & $\%_{\text {LHV }}$ & 37.9 & 37.8 & 38.2 & 38.1 & 38.8 & 38.6 & 38.8 & 38.7 \\
\hline \multicolumn{10}{|c|}{ Case 3: New build, flue gas bypass, heat integration, no $\mathrm{O}_{2}$ preheating } \\
\hline ASU & $\mathrm{kWh} / \mathrm{t}$ & 215.7 & 189.3 & 216.7 & 190.3 & 178.4 & 162.9 & 172.0 & 160.6 \\
\hline CPU & $\mathrm{kWh} / \mathrm{t}$ & 132.3 & 132.3 & 132.3 & 134.7 & 134.7 & 134.7 & 134.7 & 134.7 \\
\hline$\Delta$ Turbine & $\mathrm{kWh} / \mathrm{t}$ & -7.4 & -7.4 & -2.3 & -2.3 & -2.3 & -2.3 & -2.3 & -2.3 \\
\hline$\Delta$ Auxiliaries & $\mathrm{kWh} / \mathrm{t}$ & -3.5 & -3.2 & -6.5 & -6.1 & -6.3 & -5.6 & -6.2 & -5.6 \\
\hline Integration & $\mathrm{kWh} / \mathrm{t}$ & -79.1 & -50.9 & -95.7 & -67.5 & -81.1 & -58.4 & -73.8 & -58.4 \\
\hline Total & $\mathrm{kWh} / \mathrm{t}$ & 257.9 & 260.1 & 244.6 & 249.1 & 223.4 & 231.3 & 224.4 & 229.0 \\
\hline Efficiency loss & \%-pts & 8.0 & 8.0 & 7.6 & 7.7 & 6.9 & 7.1 & 6.9 & 7.1 \\
\hline Net efficiency & \%LHV & 38.1 & 38.1 & 38.5 & 38.4 & 39.2 & 39.0 & 39.2 & 39.0 \\
\hline \multicolumn{10}{|c|}{ Case 4: New build, flue gas bypass, heat integration, $\mathrm{O}_{2}$ preheating } \\
\hline ASU & $\mathrm{kWh} / \mathrm{t}$ & 215.7 & 189.3 & 216.7 & 190.3 & 178.4 & 162.9 & 172.0 & 160.6 \\
\hline $\mathrm{CPU}$ & $\mathrm{kWh} / \mathrm{t}$ & 132.3 & 132.3 & 132.3 & 134.7 & 134.7 & 134.7 & 134.7 & 134.7 \\
\hline$\Delta$ Turbine & $\mathrm{kWh} / \mathrm{t}$ & -7.4 & -7.4 & -2.3 & -2.3 & -2.3 & -2.3 & -2.3 & -2.3 \\
\hline$\Delta$ Auxiliaries & $\mathrm{kWh} / \mathrm{t}$ & -3.6 & -3.2 & -6.6 & -6.2 & -6.1 & -5.7 & -6.0 & -5.6 \\
\hline Integration & $\mathrm{kWh} / \mathrm{t}$ & -82.8 & -54.6 & -101.1 & -73.7 & -86.6 & -63.8 & -79.2 & -63.8 \\
\hline Total & $\mathrm{kWh} / \mathrm{t}$ & 254.2 & 256.4 & 239.0 & 242.7 & 218.1 & 225.7 & 219.2 & 223.6 \\
\hline Efficiency loss & \%-pts & 7.9 & 7.9 & 7.4 & 7.5 & 6.7 & 7.0 & 6.8 & 6.9 \\
\hline Net efficiency & $\%_{\text {LHV }}$ & 38.2 & 38.2 & 38.7 & 38.6 & 39.4 & 39.1 & 39.3 & 39.2 \\
\hline
\end{tabular}


In a context of reducing the carbon footprint of energy, heat and electricity cogeneration [22, 23, 24, 25] and solar hybridization $[25,26,27]$ have been identified as particularly promising solutions. The capability of the proposed methodology to be extended to those applications, to assess the performance of various scenarios, is illustrated below.

Heat and electricity cogeneration

The methodology described for evaluating the power plant loss of efficiency due to steam extraction can also be used to assess an order of magnitude of the tradeoff in overall efficiency between electricity and heat generation for poly-generation plant.

Three case studies have been defined regarding three different heat usages:

- $\quad$ Local Industrial steam network: saturated LP steam is generated at the power plant by steam condensation with a $10 \mathrm{~K}$ pinch. The process steam is condensed at 4 bar and sent back to the power plant at saturation temperature. Heat losses are estimated at $5 \%$ of the transported enthalpy, a 2 bar pressure drop is considered for the condensate return.

- $\quad$ Local district heating: saturated LP steam is generated at the power plant by steam condensation with a $10 \mathrm{~K}$ pinch. The process steam is condensed at 2 bar and sent back to the power plant at saturation temperature. Heat losses are estimated at $5 \%$ of the transported enthalpy, a 2 bar pressure drop is considered for the condensate return.

- Distant district heating: hot water is generated at the power plant by steam condensation with a $10 \mathrm{~K}$ pinch. The hot water is produced at saturation temperature at 1.5 bar and sent back to the power plant at $60^{\circ} \mathrm{C}$. Heat losses are estimated at $10 \%$ of the transported enthalpy, a 5 bar pressure drop is considered for the hot water loop.

For each test case, 4 sub-cases have been defined for $100 \mathrm{MW}_{\text {th }}$ and $500 \mathrm{MW}_{\text {th }}$ extracted and for a new build and retrofit cases.

Table 13 Results of the investigated heat and electricity cogeneration cases

\begin{tabular}{|c|c|c|c|c|c|c|c|}
\hline \multirow[b]{2}{*}{$\begin{array}{l}\text { Heat demand } \\
\text { Fluid }\end{array}$} & \multirow[b]{2}{*}{$\mathrm{MW}_{\text {th }}$} & \multicolumn{2}{|c|}{ Industrial steam network } & \multicolumn{2}{|c|}{ Local district heating } & \multicolumn{2}{|c|}{ Distant district heating } \\
\hline & & $\begin{array}{c}100 \\
\text { sat. steam }\end{array}$ & $\begin{array}{c}500 \\
\text { sat. steam }\end{array}$ & $\begin{array}{c}100 \\
\text { sat. steam }\end{array}$ & $\begin{array}{c}500 \\
\text { sat. steam }\end{array}$ & $\begin{array}{c}100 \\
\text { bub. water }\end{array}$ & $\begin{array}{c}500 \\
\text { bub. water }\end{array}$ \\
\hline Temperature & ${ }^{\circ} \mathrm{C}$ & 144 & 144 & 120 & 120 & 111 & 111 \\
\hline Pressure & bar & 4 & 4 & 2 & 2 & 1.5 & 1.5 \\
\hline Heat losses & $\%$ & 5 & 5 & 5 & 5 & 10 & 10 \\
\hline Pressure drop & bar & 2 & 2 & 2 & 2 & 5 & 5 \\
\hline Heat extracted & $\mathrm{MW}_{\text {th }}$ & 105 & 525 & 105 & 525 & 110 & 550 \\
\hline Liquid flow rate & $\mathrm{kg} / \mathrm{s}$ & 49 & 246 & 48 & 238 & 530 & 2630 \\
\hline Pump power & $\mathrm{MW}_{\mathrm{e}}$ & 0.013 & 0.066 & 0.013 & 0.064 & 0.35 & 1.75 \\
\hline \multicolumn{8}{|l|}{ Retrofit case } \\
\hline Parasitic loss & $\mathrm{MW}_{\mathrm{e}}$ & 28.8 & 144.2 & 28.8 & 144.0 & 32.0 & 159.8 \\
\hline Net electric eff. & $\%_{\text {LHV }}$ & 44.8 & 39.3 & 44.8 & 39.3 & 44.6 & 38.5 \\
\hline Overall eff. & \%цHV & 49.5 & 63.0 & 49.5 & 63.0 & 49.3 & 62.2 \\
\hline \multicolumn{8}{|l|}{ New build case } \\
\hline Parasitic loss & $\mathrm{MW}_{\mathrm{e}}$ & 25.4 & 127.1 & 21.0 & 105.2 & 22.3 & 111.3 \\
\hline Net electric eff. & $\%_{L H V}$ & 44.9 & 40.1 & 45.1 & 41.2 & 45.1 & 40.8 \\
\hline Overall eff. & $\%_{\text {LHV }}$ & 49.7 & 63.8 & 49.9 & 64.8 & 49.8 & 64.5 \\
\hline
\end{tabular}

The overall efficiency is defined as the ratio of energy production (thermal and electricity) over coal LHV, hence values superior to the reference power plant net efficiency.

\section{$\underline{\text { Solar hybridization }}$}

Another potential application of the proposed methodology is the assessment of the low to medium temperature solar power plant hybridization. For this application, two major technologies can be considered: Fresnel collectors and parabolic trough collectors [27]. Linear Fresnel collectors or parabolic troughs can produce hot thermal oil at $350{ }^{\circ} \mathrm{C}$. Alternatively, linear Fresnel collector can produce directly saturated medium pressure steam. Finally, evacuated tube solar collectors are able to produce pressurized water at $150{ }^{\circ} \mathrm{C}$ or low pressure steam. With the heat integration correlation, a preliminary evaluation of the solar marginal efficiency and solar share can be performed.

Four case studies have been defined regarding two types of solar collectors: linear Fresnel collectors and evacuated tube collectors, with two different integration strategies for both technologies:

- Production of 40 bar saturated steam by linear Fresnel collector from $50{ }^{\circ} \mathrm{C}$ feedwater. The heat is integrated in the steam cycle feedwater preheater from 250 to $50{ }^{\circ} \mathrm{C}$. A 10 bar pressure drop is considered in this heat exchanger/solar collector loop.

- Production of 40 bar saturated steam by linear Fresnel collectors from bubbling water at the same pressure. The heat is integrated in the appropriate feedwater preheater. A 5 bar pressure drop is considered in this heat exchanger/solar collector loop. 
- $\quad$ Production of 2 bar saturated steam by evacuated tube collectors from 2 bar bubbling water at the same pressure. The heat is integrated in the appropriate feedwater preheater. A 3 bar pressure drop is considered in this heat exchanger/solar collector loop.

- Production of hot water at $120^{\circ} \mathrm{C}$ by evacuated tube collectors from $50^{\circ} \mathrm{C}$ feedwater. The heat is integrated in the steam cycle feedwater preheater from 120 to $50^{\circ} \mathrm{C} . \mathrm{A} 5$ bar pressure drop is considered in this heat exchanger/solar collector loop.

For each test case, 2 sub-cases have been defined for $50 \mathrm{MW}_{\text {th }}$ and, a maximum of, $200 \mathrm{MW}_{\text {th }}$ heat generated by solar collectors.

Table 14 Results of the investigated solar hybridization cases

\begin{tabular}{|c|c|c|c|c|c|c|c|c|c|}
\hline \multirow[b]{3}{*}{$\begin{array}{l}\text { Solar heat } \\
\text { Fluid }\end{array}$} & \multirow[b]{3}{*}{$\mathrm{MW}_{\text {th }}$} & \multicolumn{4}{|c|}{ Linear Fresnel collectors } & \multicolumn{4}{|c|}{ Evacuated tubes collectors } \\
\hline & & \multicolumn{2}{|c|}{ One preheater } & \multicolumn{2}{|c|}{ Multiple preheaters } & \multicolumn{2}{|c|}{ One preheater } & \multicolumn{2}{|c|}{ Multiple preheaters } \\
\hline & & $\begin{array}{c}50 \\
\text { sat. steam }\end{array}$ & $\begin{array}{c}79 * \\
\text { sat. steam }\end{array}$ & $\begin{array}{c}50 \\
\text { sat. steam }\end{array}$ & $\begin{array}{c}200 \\
\text { sat. steam }\end{array}$ & $\begin{array}{c}50 \\
\text { sat. steam }\end{array}$ & $\begin{array}{c}77^{*} \\
\text { sat. steam }\end{array}$ & $\begin{array}{c}50 \\
\text { bub. water }\end{array}$ & $\begin{array}{c}153^{*} \\
\text { bub. water }\end{array}$ \\
\hline Pressure & bar & 40 & 40 & 40 & 40 & 2 & 2 & 2 & 2 \\
\hline Temperature & ${ }^{\circ} \mathrm{C}$ & 250 & 250 & 250 & 250 & 120 & 120 & 120 & 120 \\
\hline Return Temp. & ${ }^{\circ} \mathrm{C}$ & 250 & 250 & 50 & 50 & 120 & 120 & 50 & 50 \\
\hline Pressure drop & bar & 5 & 5 & 10 & 10 & 3 & 3 & 5 & 5 \\
\hline Liquid flow rate & $\mathrm{kg} / \mathrm{s}$ & 29.3 & 46.3 & 19.3 & 77.3 & 23.8 & 36.6 & 170 & 520 \\
\hline Pump power & $\mathrm{MW}_{\mathrm{e}}$ & 0.020 & 0.031 & 0.026 & 0.10 & 0.010 & 0.014 & 0.11 & 0.35 \\
\hline Latent heat frac. & $\%$ & 100 & 100 & 66 & 66 & 100 & 100 & 0 & 0 \\
\hline Net efficiency & \% \%HV & 47.0 & 47.5 & 46.9 & 49.1 & 46.5 & 46.7 & 46.5 & 47.1 \\
\hline Solar efficiency & $\%$ & 36.3 & 36.3 & 32.3 & 31.2 & 16.1 & 16.1 & 13.2 & 12.4 \\
\hline Solar production & $\mathrm{MW}_{\mathrm{e}}$ & 18.1 & 28.7 & 16.1 & 62.4 & 8.0 & 12.4 & 6.6 & 19.0 \\
\hline Solar share & $\%$ & 1.86 & 2.94 & 1.65 & 6.40 & 0.82 & 1.27 & 0.68 & 1.95 \\
\hline
\end{tabular}

${ }^{*}$ heat limited due to the saturation of preheaters

\section{Discussion and perspective}

As seen in the previous sections, the developed correlations can be used to evaluate retrofit as well as new built cases. In fact, these correlations can be adapted for different studies. For example, the isentropic efficiency of the auxiliary expansion turbine for the steam extraction can be adapted to represent a retrofit with a value between 75 and $85 \%$ or the extension of the IP turbine with a value between 90 to $94 \%$. Other examples are the pinches considered both for heat generation or heat valorisation or the fraction of waste heat considered for valorisation.

This framework can be refined with more detailed heat losses and pressure drops in pipes to fit a specific project. In particular, these energetic performance calculations can be enhanced by technical-economic evaluation. Whilst for newbuilt studies, where typical economic hypotheses considered for cost analysis in power plant applications lead to a tradeoff between capital expenditure and operational expenditure largely leaning towards the minimization of the latter, the approximation consisting in realizing the comparison between different plant layouts solely on an energetic basis can be valid, other frameworks could lead to the necessity to consider economic criterion. In order to assess the plant lifetime benefit of a given integration option, technical-economic evaluation need to be carried out. Especially with respect to heat exchangers pinches (cost), piping lengths (pressure drop and cost) and main equipment modifications (such as adiabatic compressor vs intercooled compressor).

Moreover, the impact of tight heat integration on plant availability and flexibility can be a concern, especially for loadfollowing power plant. The waste heat valorization detailed in this study is not detrimental to the power plant availability since it is built in parallel to the existing feedwater preheating train. If the integration is lost for any reason; the feedwater preheating is mechanically ensured by an increased steam bleeding in the next preheater, driven by the equilibrium vapor pressure. Thus, a heat integration loss induces an efficiency drop of the power plant but the overall plant availability decrease is modest.

The core hypothesis of this work is that all heat is extracted or integrated within the steam cycle; other integration options can be considered, such as air preheating, flue gases cooling, coal drying or direct heat integration in the $\mathrm{CO}_{2}$ capture process. While these integration options are not foreseen to be more efficient than the steam cycle integration, they can increase the maximal amount of waste heat which can be integrated. Therefore, these correlations does not represent the maximal integration which can be expected between the power plant and the capture plant but represent a 'not so' conservative point of view for heat integration with respect to the standard practice in large size power plant. Also, it has to be stressed that the heat integration methodology proposed within this article is only valid for the considered steam cycle (steam conditions, turbines isentropic efficiencies, condensing pressure, number of feedwater preheaters, ...). Indeed, the proposed 
correlations, marginal efficiencies as well as the established coefficients are cycle specific. However, the methodology could fairly easily be adapted if an integration study on, for instance, a specific existing power plant or a conceptual advanced ultrasupercritical cycle was targeted.

It should be reminded that the method proposed in this paper is specific to an integration with the supercritical coal-fired power plant defined earlier. However, the calculation procedure and associated equations are not restricted to a specific case and a more generic approach could be adopted by considering steam cycle dependant coefficients. Consequently, other sets of coefficients could be derived for other cases (such as subcritical or advanced ultra-supercritical coal plants, natural gas or nuclear power plants) by carrying out a design of experiments using a process simulator and regressing new coefficients using the equations described in this paper.

Finally, the performance assessment for retrofit cases could be further refined by considering the steam turbines performance maps. Indeed, since the integration of waste heat induces steam bleedings reductions, the volume flowrate across the turbines are modified, impacting the isentropic efficiencies. High temperature heat valorization (integration in PHX-7 and 8), for retrofit case, could also be slightly improved. The surface area of the steam resuperheater being fixed, a steam flowrate reduction induces an increase of the tubes surface temperature since the tube-side heat capacity is reduced. Thus, a maximum allowable thermal stress on the boiler material could be considered to realistically assess the integrated system efficiency for a retrofit case.

\section{Conclusion}

A set of correlations has been derived from rigorous calculations on a state of the art pulverized bituminous coal-fired power plant.These correlations can be used to evaluate retrofit as well as new build cases; and both steam extractions (up to 700 $\mathrm{MW}_{\text {th }}$ from 50 to $170^{\circ} \mathrm{C}$ ) and waste heat integration (up to $310^{\circ} \mathrm{C}$ in the limit of preheater saturation)have been considered. Additionally, estimation of the cooling water pump work and $\mathrm{CO}_{2}$ compression work are provided. While initially developed for $\mathrm{CO}_{2}$ capture applications, the proposed methodology can conveniently be used to evaluate other technologies.

In this paper, the potential use of the developed methodology has been highlighted through several comprehensive case studies. Different process layouts and scenario have been compared on a consistent basis for both post- and oxy-combustion $\mathrm{CO}_{2}$ capture, showing how different cases could be conveniently assessed with relatively few input data. For instance, this approach could easily be applied to assess innovative concepts such as the staged pressurized oxy-combustion system described by [28] and compare the integrated process performance with other technologies, as carried out in [29]. To illustrate the capability of the approach to tackle other applications, several case studies have been proposed for the realistic assessment of the influence of heat and electricity cogeneration (local industrial steam network, local district heating and distant district heating) as well as low to medium temperature solar energy hybridization (linear Fresnel collectors and evacuated tube collectors) on the coal-fired power plant efficiency. While not considered within this study, other systems such as biomass hybridization (auxiliary boiler), high temperature solar hybridization and industrial waste heat valorization in the frame of industrial ecology studies are few examples of potential application that can be assessed within the framework defined in this work.

Finally, a turnkey Microsoft Excel spreadsheet is provided for users that are willing to quickly obtain a realistic figure depicting the influence of thermal integration of a given system on the energetic performance of a state-of-the-art coal-fired power plant.

\section{Supporting information}

The spreadsheet (Microsoft Excel 2010) is publically available online, the authors and EDF do not engage on results obtained by the user.

\section{Nomenclature}

e Power plant $\mathrm{CO}_{2}$ emissions $\left(\mathrm{kg}_{\mathrm{CO} 2} / \mathrm{kWh}\right)$

$\dot{m}_{\mathrm{CO}_{2}} \quad$ Flux of captured $\mathrm{CO}_{2}\left(\mathrm{t}_{\mathrm{CO} 2} / \mathrm{h}\right)$

$\mathrm{T} \quad$ Temperature $\left({ }^{\circ} \mathrm{C}\right)$

P Pressure (bar)

$Q \quad$ Thermal power $\left(\mathrm{MW}_{\mathrm{th}}\right)$

$q \quad$ Specific heat duty $\left(\mathrm{GJ} / \mathrm{t}_{\mathrm{CO} 2}\right)$

$x \quad$ Fraction of steam extracted

$W \quad$ Electric power $\left(\mathrm{MW}_{\mathrm{e}}\right)$

$w \quad$ Specific electric power $\left(\mathrm{kWh} / \mathrm{t}_{\mathrm{CO} 2}\right)$

$\eta \quad$ Plant efficiency (\% \% 
CCS Carbon Capture and Storage

CPU Compression and Purification Unit

FGD Flue Gas Desulfurization

FW Feedwater

FWH Feedwater Heater

HP High Pressure

ICA Intercooled Absorber

IP / MP Intermediate / Medium Pressure

LP Low Pressure

LVC Lean Vapor Compression

PHX Parallel Heat Exchanger

$\mathrm{RH} \quad$ Regenerative Heater 


\section{References}

[1] Liebenthal U, Linnenberg S, Oexmann J, Kather A, Derivation of correlations to evaluate the impact of retrofitted postcombustion $\mathrm{CO} 2$ capture processes on steam power plant performance. International Journal of Greenhouse Gas Control 2011; 5: 1232-1239.

[2] Lucquiaud $\mathrm{M}$, Gibbins J, On the integration of $\mathrm{CO}_{2}$ capture with coal-fired power plants: A methodology to assess and optimise solvent-based post-combustion capture systems. Chemical Engineering Research \& Design 2011; 89: 1553-1571.

[3] Oyenekan BA, Rochelle GT, Alternative stripper configurations for $\mathrm{CO}_{2}$ capture by aqueous amines. AIChE Journal 2007; 53: $3144-3154$

[4] Romeo LM, Espatolero S, Bolea I, Designing a supercritical steam cycle to integrate the energy requirements of $\mathrm{CO}_{2}$ amine scrubbing. International Journal of Greenhouse Gas Control 2008; 2: 563-570.

[5] Fu C, Anantharaman R, Gundersen T, Optimal integration of compression heat with regenerative steam Rankine cycles, Computer Aided Chemical Engineering 2014; 34: 519-524.

[6] Soundararajan R, Anantharaman R, Gundersen T, Design of Steam Cycles for Oxy-combustion Coal based Power Plants with Emphasis on Heat Integration, Energy Procedia 2014; 51: 119-126.

[7] Goto K, Yogo K, Higashii T, A review of efficiency penalty in a coal-fired power plant with post-combustion CO2 capture, Applied Energy 2013; 111: 710-720.

[8] Manzolini G, Sanchez Fernandez E, Rezvani S, Macchi E, Goethe ELV, Vlugt TJH, Economic assessment of novel amine based $\mathrm{CO}_{2}$ capture technologies integrated in power plants based on European Benchmarking Task Force methodology, Applied Energy 2015, 138, 546-558.

[9] European Benchmarking Task Force. European best practice guidelines for assessment of $\mathrm{CO}_{2}$ capture technologies, public report from CAESAR, CESAR and DECARBit European Union Projects, Brussels, Belgium; 2011.

[10] Jovanovic S, Stoffregen TS, Clausen I, Sieder G, Techno-economic analysis of 550 MWe subcritical PC power plant with $\mathrm{CO}_{2}$ capture. Submitted under funding opportunity announcement, DE-FOA-0000403, Linde LLC \& BASF; 2012.

[11] lijima M, Kadono K, Kaibara K, Carbon dioxide recovery system. Patent US2012/0269690.

[12] Knudsen JN, Andersen A, Jensen JN, Biede O, Results from test campaigns at the $1 \mathrm{t} / \mathrm{h} \mathrm{CO}_{2}$ PCC pilot plant in Esbjerg under the EU FP7 CESAR project. 1st Post Combustion Capture Conference, Abu Dhabi, may 17-19; 2011.

[13] Tenaska Trailblazer Partners, Final Front-End Engineering and Design Study Report. Report to the Global CCS Institute; 2012.

[14] Kingsnorth Carbon Dioxide Capture and Storage Demonstration Project, Chapter 5 - Technical design PCC and compression plant; 2011.

[15] Edvardsson T, Chopin F, Recent developments on advanced amine process technology \& demonstration unit operations, Power-Gen Europe, Cologne, june, 12-14; 2012.

[16] Yokoyama K, Takamoto S, Kikkawa H, Katsube T, Nakamoto T, Oda N, Kawasaki T, Sugiura T, Wu S, Eswaran S, Schreir W, Heberle A, Pavlish B, Hitachi's carbon dioxide scrubbing technology with new absorbent for coal-fired power plants. Energy Procedia 2011; 4: 245-252.

[17] Hunt $\mathrm{M}$, Post combustion $\mathrm{CO}_{2}$ capture - Lab scale testing to full scale deployment, Power-Gen Europe, Cologne, june, $12-14 ; 2012$.

[18] Hu Y, Yan J, Li H, Effects of flue gas recycle on oxy-coal power generation systems, Applied Energy 2012; 97: 255-263.

[19] Davidian B, Process and unit for the separation of air by cryogenic distillation. US patent, US2012/0285197 A1.

[20] Dillon DJ, White V, Allam RJ, Wall RA, Gibbins J, Oxy-combustion processes for $\mathrm{CO}_{2}$ capture from power plant.IEA Report No: E/04/031 Issue 1; 2005.

[21] Hagi H, Nemer M, Le Moullec Y, Bouallou C, Performance assessment of first generation oxy-coal power plantsthrough an exergy-based process integration methodology. Energy 2014; 69: 272-284.

[22] Lund R., Mathiesen B.V., 2015, Large combined heat and power plants in sustainable energy systems, Applied Energy, 142, 389-395.

[23] Kelly KA, McManus MC, Hammond GP, An energy and carbon life cycle assessment of industrial CHP (combined heat and power) in the context of a low carbon UK. Energy 2014; 77: 812-821. 
[24] Liao C, Ertesvag IS, Zhao J, Energetic and exergetic efficiencies of coal-fired CHP (combined heat and power) plants used in district heating systems of China. Energy 2013; 57: 671-681

[25] Nixon JD, Dey PK, Davies PA, The feasibility of hybrid solar-biomass power plants in India. Energy 2012; 46: 541-554.

[26] Hong-juan H, Zhen-yue Y, Yong-ping T, Si C, Na L, Jungie W, Performance evaluation of solar aided feedwater heating of coal-fired power generation (SAFHCPG) system under different operating conditions, Applied Energy 2013; 112: 710-718.

[27] Zhao Y, Hong H, Jin H, Mid and low-temperature solar-coal hybridization mechanism and validation. Energy 2014; 74: 7887.

[28] Gopan A, Kumfer BM, Phillips J, Thimsen D, Smith R, Axelbaum RL, Process design and performance analysis of a Staged Pressurized Oxy-Combustion power plant for carbon capture, Applied Energy 2014; 125: 179-188.

[29] Hagi H, Nemer M, Le Moullec Y, Bouallou C, Towards Second Generation Oxy-pulverized Coal Power Plants: Energy Penalty Reduction Potential of Pressurized Oxy-combustion Systems, Energy Procedia 2014; 63: 431-439. 


\section{Appendix A}

Major modeling hypotheses

\begin{tabular}{|c|c|c|c|}
\hline \multirow[t]{4}{*}{ Boiler } & Heat losses through walls & $\%_{\text {coal }}($ LHV base) & 0.25 \\
\hline & Unconverted carbon & $\%$ & 1 \\
\hline & Pressure & Bar & 1.0035 \\
\hline & Heat losses duct (primary steam/reheat steam) & ${ }^{\circ} \mathrm{C}$ & $2 / 2$ \\
\hline \multirow[t]{4}{*}{ Pumps } & Mechanical efficiency & $\%$ & 95 \\
\hline & Efficiency (>10MW) & $\%$ & 80 \\
\hline & Efficiency (<10MW) & $\%$ & 75 \\
\hline & Efficiency (vacuum pump) & $\%$ & 65 \\
\hline \multirow[t]{3}{*}{ Fans } & Mechanical efficiency & $\%$ & 95 \\
\hline & Isentropic efficiency (Forced draft) & $\%$ & 70 \\
\hline & Isentropic efficiency (Induced draft) & $\%$ & 80 \\
\hline \multirow[t]{7}{*}{ Turbines } & Mechanical efficiency & $\%$ & 99.5 \\
\hline & Isentropic efficiency (>50 bar) & $\%$ & 92 \\
\hline & Isentropic efficiency (>5 bar) & $\%$ & 94 \\
\hline & Isentropic efficiency (<5 bar) & $\%$ & 90 \\
\hline & Isentropic efficiency (<5 bar, condensation) & $\%$ & 88 \\
\hline & Turbo alternator electrical efficiency & $\%$ & 98.5 \\
\hline & Transformer electrical efficiency & $\%$ & 99.6 \\
\hline \multirow[t]{8}{*}{ Pressure drop } & LP steam bleeding/ HP steam bleeding & $\%$ & $3 / 3$ \\
\hline & LP FWH train / HP FWH train & $\%$ & $5 / 5$ \\
\hline & Steam superheat / Steam resuperheat & $\%$ & $7 / 8$ \\
\hline & Cooling water train & Bar & 2.3 \\
\hline & Primary air train & mbar & 120 \\
\hline & Secondary air train & mbar & 25 \\
\hline & Flue gas train & mbar & 100 \\
\hline & FGD slurry loop & Bar & 8 \\
\hline \multirow[t]{5}{*}{ Pinch } & Economizer & $\mathrm{K}$ & 25 \\
\hline & FW preheater (at saturation) & K & 5 \\
\hline & Air preheater & K & 30 \\
\hline & Gas - Liquid heat exchange & K & 10 \\
\hline & Gas - Gas heat exchange & K & 20 \\
\hline \multirow[t]{7}{*}{ Misc. auxiliaries } & Coal handling & $\mathrm{kWh} / \mathrm{t}_{\text {coal }}$ & 15 \\
\hline & Ash handling & $\mathrm{kWh} / \mathrm{t}_{\text {coal }}$ & 16 \\
\hline & Limestone preparation and handling & $\mathrm{kWh} / \mathrm{t}_{\text {coal }}$ & 3.6 \\
\hline & Gypsum preparation and handling & $\mathrm{kWh} / \mathrm{t}_{\text {coal }}$ & 24 \\
\hline & SCR & $\mathrm{kWh} / \mathrm{t}_{\text {coal }}$ & 1 \\
\hline & ESP & $\mathrm{kWh} / \mathrm{t}_{\text {coal }}$ & 6.6 \\
\hline & Miscellaneous consumption and utilities & $\% \mathrm{P}_{\text {Grosselec }}$ & 0.5 \\
\hline \multirow[t]{5}{*}{ Leaks } & Air ingress in boiler (air-combustion) & \%FG flow (wt) & 1.5 \\
\hline & Air ingress in ESP(air-combustion) & \%FG flow (wt) & 5 \\
\hline & PA leak to SA (Ljungstrom) & \%pa flow (wt) & 10 \\
\hline & SA leak to flue gas (Ljungstrom) & $\%_{\text {SA flow }}(w t)$ & 5 \\
\hline & Repartition of the leaks & hot end/cold end & $70 / 30$ \\
\hline
\end{tabular}

